\title{
The "Spaghetti Project": the final identification guide to European Terebellidae (sensu lato) (Annelida, Terebelliformia)
}

\author{
Nicolas LAVESQUE ${ }^{\circledR 1, *}$, Pat HUTCHINGS ${ }^{2}$, Mario H. LONDOÑO-MESA ${ }^{3}$, \\ João M.M. NOGUEIRA ${ }^{4}$, Guillemine DAFFE ${ }^{5}$, Arne NYGREN $^{6}$, Hugues BLANCHET ${ }^{7}$, \\ Paulo BONIFÁCIO ${ }^{8}$, Caroline BROUDIN ${ }^{9}$, Jean-Claude DAUVIN ${ }^{10}$, Gabin DROUAL ${ }^{11}$, \\ Benoit GOUILLIEUX ${ }^{12}$, Jacques GRALL ${ }^{13}$, Benjamin GUYONNET ${ }^{14}$, Céline HOUBIN ${ }^{15}$, \\ Suzie HUMBERT ${ }^{16}$, Anne-Laure JANSON ${ }^{17}$, Jérôme JOURDE ${ }^{18}$, Céline LABRUNE ${ }^{19}$, \\ Bastien LAMARQUE ${ }^{20}$, Lise LATRY ${ }^{21}$, Vincent LE GARREC ${ }^{22}$, Corine PELAPRAT ${ }^{23}$, \\ Jean-Philippe PEZY ${ }^{24}$, Pierre-Guy SAURIAU ${ }^{25}$ \& Xavier DE MONTAUDOUIN ${ }^{26}$ \\ 1,7,12,16,20,21,26 CNRS, Univ. Bordeaux, EPOC, UMR 5805, Station Marine d'Arcachon, Arcachon, France. \\ ${ }^{2}$ Australian Museum Research Institute, Australian Museum, Sydney, Australia; \\ Department of Biological Sciences, Macquarie University, Australia. \\ ${ }^{3}$ Grupo LimnoBasE y Biotamar, Instituto de Biología Facultad de Ciencias Exactas y Naturales, \\ Universidad de Antioquia, Medellín, Colombia. \\ ${ }^{4}$ Laboratório de Poliquetologia, Departamento de Zoologia, Instituto de Biociências, \\ Universidade de São Paulo, Brazil. \\ ${ }^{5}$ CNRS, Université de Bordeaux, Observatoire Aquitain des Sciences de l'Univers, \\ UMS 2567 POREA, Pessac, France. \\ ${ }^{6}$ Sjöfartmuseet Akvariet, Göteborg, Sweden; Institutionen för marina vetenskaper, \\ Göteborgs Universitet, Göteborg, Sweden. \\ ${ }^{8}$ Independent researcher, Brest, France. \\ ${ }^{9,15}$ Sorbonne Université, CNRS, Station Biologique de Roscoff, 29680 Roscoff, France. \\ ${ }^{10,24}$ Normandie Univ, UNICAEN, UNIROUEN, Laboratoire Morphodynamique Continentale et \\ Côtière, CNRS UMR 6143 M2C, Caen, France. \\ ${ }^{11}$ Ifremer, DYNECO-LEBCO, Plouzané, France; Ifremer, EMH, Nantes, France. \\ ${ }^{13,22}$ Univ Brest, CNRS, IRD, OSU-IUEM, Plouzané, France. \\ ${ }^{14}$ TBM Environnement, Auray, France. \\ ${ }^{17}$ OFB, CNRS, MNHN, UMS 2006 Patrimoine Naturel, Station Marine de Dinard, Dinard, France. \\ ${ }^{18,25}$ CNRS, La Rochelle Université, Littoral Environnement et Sociétés, \\ UMR 7266 LIENSs, La Rochelle, France. \\ ${ }^{19} \mathrm{CNRS}$, Sorbonne Université, Laboratoire d'Ecogéochimie des Environnements Benthiques, \\ LECOB, Banyuls, France. \\ ${ }^{23}$ Benthos Identification, 33840 Escaudes, France; Stareso, Calvi, France. \\ ${ }^{1, *}$ Corresponding author: nicolas.lavesque@u-bordeaux.fr \\ 2Email: pat.hutchings@Australian.Museum \\ 32Email: hernan.londono@udea.edu.co \\ [4Email: nogueira@ib.usp.br \\ 5Email: guillemine.daffe@u-bordeaux.fr
}


${ }^{6}$ Email: maskmedmera@gmail.com

7Email: hugues.blanchet@u-bordeaux.fr

8Email: bonif@me.com

${ }^{9}$ Email: broudin@sb-roscoff.fr

${ }^{10}$ Email: jean-claude.dauvin@unicaen.fr

${ }^{11}$ Email: Gabin.Droual@ifremer.fr

${ }^{12}$ Email: benoit.gouillieux@u-bordeaux.fr

${ }^{13}$ Email: jacques.grall@univ-brest.fr

${ }^{14}$ Email: b.guyonnet@tbm-environnement.com

${ }^{15}$ Email: houbin@sb-roscoff.fr

${ }^{16}$ Email: suzie.humbert@u-bordeaux.fr

${ }^{17}$ Email: anne-laure.janson@mnhn.fr

${ }^{18}$ Email: jjourde@univ-lr.fr

${ }^{19}$ Email: celine.labrune@obs-banyuls.fr

${ }^{20}$ Email: bastien.lamarque@u-bordeaux.fr

${ }^{21}$ Email: lise.latry@u-bordeaux.fr

${ }^{22}$ Email: Vincent.Legarrec@univ-brest.fr

${ }^{23}$ Email: benthid@gmail.com

${ }^{24}$ Email: jean-philippe.pezy@unicaen.fr

${ }^{25}$ Email: pierre-guy.sauriau@univ-lr.fr

${ }^{26}$ Email: xavier.de-montaudouin@u-bordeaux.fr

${ }^{1}$ urn:1sid:zoobank.org:author:3E6771E7-1A94-4FD2-8E7B-36AD6ED8B446

${ }^{2}$ urn:1sid:zoobank.org:author:E83A37D3-33D8-4999-ACA6-8DFECAF05D11

${ }^{3}$ urn:1sid:zoobank.org:author:198696D8-8FB2-4F03-AFEB-0E0773CB6669

${ }^{4}$ urn:lsid:zoobank.org:author:C40C8C12-619D-4EC2-8998-253708120D3F

${ }^{5}$ urn:1sid:zoobank.org:author:BC283B5F-3757-4941-BEED-4004C6850912

${ }^{6}$ urn:lsid:zoobank.org:author:46801B86-2D81-4702-A1D1-65E1C6C40FC1

${ }^{7}$ urn:1sid:zoobank.org:author:47011CCC-0911-4EB5-9EBA-9BAF5394D042

${ }^{8}$ urn:1sid:zoobank.org:author:19882300-C635-4CF2-A7CE-98EE01C87120

${ }^{9}$ urn:lsid:zoobank.org:author:0CE07B72-5E59-4A7F-8F04-D77A1167CBAB

${ }^{10}$ urn:lsid:zoobank.org:author:12B3072A-421D-47A0-82BE-10125016C8D9

${ }^{11}$ urn:1sid:zoobank.org:author:C3137160-D1C5-4996-91D7-A3F4E38E25DD

${ }^{12}$ urn:1sid:zoobank.org:author:D0BE2D38-05DC-4DE0-BEE2-D458ED5C3299

${ }^{13}$ urn:1sid:zoobank.org:author:74F9A220-94E5-4C80-B375-0FD4C894F804

${ }^{14}$ urn:lsid:zoobank.org:author:82664894-3735-4CA4-8443-D904052FE3CF

${ }^{15}$ urn:lsid:zoobank.org:author:41D368C7-3084-4E8A-B6EF-24E184D4752E

${ }^{16}$ urn:lsid:zoobank.org:author:4354F19C-8567-4713-8E3B-492B4025EF26

${ }^{17}$ urn:lsid:zoobank.org:author:587C0411-5819-4FEB-AD5F-A0107D72A725

${ }^{18}$ urn:1sid:zoobank.org:author:746DEE71-E146-4355-B164-D55D9A971044

${ }^{19}$ urn:lsid:zoobank.org:author:9200C8BA-E199-46B8-8727-BCF01DBC383A

${ }^{20}$ urn:1sid:zoobank.org:author:BE414235-3305-483C-8ED2-53AF7F68482A

${ }^{21}$ urn:lsid:zoobank.org:author:9F307F07-9830-4AE7-A77C-397BA3B8BE19

${ }^{22}$ urn:1sid:zoobank.org:author:00E7C229-D215-4035-96C5-43B072EFC28A

${ }^{23}$ urn:1sid:zoobank.org:author:AD117DA7-DFA1-4190-BA8B-4958AF593822

${ }^{24}$ urn:1sid:zoobank.org:author:9307F067-DF5F-4BF1-B7EF-9B876640B891

${ }^{25}$ urn:lsid:zoobank.org:author:C5012CB5-D12A-468F-9536-E0C08F9A91E6

${ }^{26}$ urn:1sid:zoobank.org:author:D90D06BE-E569-4B4B-98F4-AFB1E183C2A5 


\begin{abstract}
This paper is the conclusion of the "Spaghetti Project" aiming to revise French species of Terebellidae sensu lato (s.1.) belonging to the five families: Polycirridae, Telothelepodidae, Terebellidae sensu stricto (s.s.), Thelepodidae and Trichobranchidae. During this project, 41 species were observed, 31 of them new for science: eight species of Polycirridae, eleven species of Terebellidae s.s., three species of Thelepodidae and nine species of Trichobranchidae. We provide a comprehensive key for all European species of terebellids with a focus on the important diagnostic characters for each family. Finally, we discuss issues on taxonomy, biodiversity and cryptic and pseudo-cryptic species of polychaetes in European waters, based on results obtained during this project.
\end{abstract}

Keywords. Taxonomy, terebellids, spaghetti worms, cryptic species, identification key.

Lavesque N., Hutchings P., Londoño-Mesa M.H., Nogueira J.M.M., Daffe G., Nygren A., Blanchet H., Bonifácio P., Broudin C., Dauvin J.-C., Droual G., Gouillieux B., Grall J., Guyonnet B., Houbin C., Humbert S., Janson A.-L., Jourde J., Labrune C., Lamarque B., Latry L., Le Garrec V., Pelaprat C., Pezy J.-P., Sauriau P.-G. \& De Montaudouin X. 2021. The "Spaghetti Project": the final identification guide to European Terebellidae (sensu lato) (Annelida, Terebelliformia). European Journal of Taxonomy 782: 108-156.

https://doi.org/10.5852/ejt.2021.782.1593

\title{
Introduction
}

This is the concluding paper of the series devoted to the "Spaghetti Project" which aims to revise the French species of Terebellidae sensu lato (s.l.), referring to the original taxa previously considered as subfamilies of the family Terebellidae Johnston, 1846, namely Polycirrinae Malmgren, 1866 (now referred to Polycirridae), Terebellinae Johnston, 1846 (now referred to Terebellidae sensu stricto (s.s.)) and Thelepodidae Hessle, 1917, together with the closely related family Trichobranchidae Malmgren, 1866 and the recently described family Telothelepodidae Nogueira, Fitzhugh \& Hutchings, 2013 (Johnston 1846; Malmgren 1866; Hessle 1917; Nogueira et al. 2013; Hutchings et al. 2021a).

These tubiculous polychaetes are characterised by the presence of numerous grooved buccal tentacles used for selective deposit feeding, rendering these animals the name of "Spaghetti worms" (Hutchings et al. 2021b). These tentacles are of prostomial origin and not retractable into the mouth. They are generally smooth, except for in some polycirrids where they are papillose. Most of the terebellids are sedentary worms found in all marine environments, from the intertidal to the abyss and are common worldwide, distributed from polar to tropical regions (Hutchings et al. 2021b). The five families belonging to Terebellidae (s.l.) can be separated from each other by the morphology of the upper lip, the shape and number of branchiae, the glandular areas of ventral segments, the neuropodia and the arrangement of the uncini of anterior segments (i.e., in single or double rows) (Hutchings et al. 2021b).

The "Spaghetti Project" was initiated when the first author realized that the taxonomy of these worms in France, but also in Europe, was poorly documented. Indeed, the lack of accurate literature and the absence of useful and up-to-date keys of identification for this part of the world has led to their misidentifications for decades. In 2016, after observations of several specimens of Terebelliformia during a national workshop (at Arcachon, conducted by Mario Londoño-Mesa) and a national taxonomic course (at Caen, conducted by Pat Hutchings), we realized that many of the species required in-depth investigations. This collaborative project involved all benthic taxonomists at all French marine stations (RESOMAR network) who sent us fresh material as well as specimens stored in local collections. The first part of the project, devoted to the Trichobranchidae, allowed us to describe nine new species along the French coasts (Lavesque et al. 2019a). The second paper, focused on Telothelepodidae and Thelepodidae, described three new species (Lavesque et al. 2020a) and the third one on Polycirridae described eight new species (Lavesque et al. 2020b). Finally, the fourth paper dealt with the Terebellidae sensu stricto (s.s.) and included the description of nine species (Lavesque et al. 2021). With the previous descriptions 
of Lomia ramzega Lavesque, Bonifácio, Londoño-Mesa, Le Garrec \& Grall, 2017 from Brittany and Pista colini Labrune, Lavesque, Bonifácio \& Hutchings, 2019 from the Gulf of Lion (Lavesque et al. 2017a; Labrune et al. 2019), a total of 31 new species have been described from French waters in the past five years, combining both morphological and molecular data. This "Spaghetti Project" is thus an excellent example of what can be done by working in a network, with limited funding but enthusiastic people.

The main objectives of this last paper are (1) to provide a comprehensive key for all European species of terebellids (s.1.) with a focus on important diagnostic characters for each family and (2) to discuss the main results obtained during this project.

\section{Material and methods}

During the "Spaghetti Project", morphological observations were conducted on specimens stored in the MNHN collection and specimens collected during different research programs and specific samplings along the French coasts (see previous papers).

Specimens were fixed in $4 \%$ formaldehyde in filtered seawater solution, washed and then, transferred to $70 \%$ ethanol for preservation. Methyl green, which can be washed out, was used to reveal the abundant glandular areas and to highlight the ornamentation of these areas, which are difficult to observe otherwise. For the molecular studies, several parapodia were removed from several fresh specimens, or from specimens fixed in $96 \%$ ethanol.

Preserved specimens were examined under a Nikon SMZ25 stereo microscope and a Nikon Eclipse $\mathrm{Ci}$ microscope, and photographed with a Nikon DS-Ri 2 digital camera. Dehydrated specimens used for examination by scanning electron microscopy (SEM) were prepared by critical point drying, coated with gold and examined and photographed with JEOL JSM 6480LA at Macquarie University, Sydney and Hitachi TM3030 at Arcachon Marine Station.

Morphological terminology follows Nogueira et al. (2010) and Hutchings et al. (2021a), especially concerning the anterior end and the general structure of the uncini (Fig. 1), Glasby \& Hutchings (2014) for the types of uncini present in Polycirrus species and Parapar et al. (2020a, 2020b) for those found in Terebellides species.

Authorities of each species are given in the different keys and cited in the references.

\section{Abbreviations}

$$
\begin{aligned}
& \mathrm{CH}=\text { Chaetiger } \\
& \mathrm{MG}=\text { Methyl green } \\
& \mathrm{SEM}=\text { Scanning Electron Microscope } \\
& \mathrm{SG}=\text { Segment }
\end{aligned}
$$

\section{Repositories}

$\begin{array}{ll}\text { AM } & =\text { Australian Museum, Sydney, Australia } \\ \text { CEMUA } & =\text { Colección Estuarina y Marina, Universidad de Antioquia in Medellín, Colombia } \\ \text { GNM } & =\text { Göteborg Natural History Museum, Sweden } \\ \text { KGB } & =\text { Department of Hydrobiology, Moscow Lomonosov State University, Russia } \\ \text { LACM } & =\text { Natural History Museum of Los Angeles County, Los Angeles, USA } \\ \text { MNHB } & =\text { Museum der Naturkunde für Humboldt Universität zu Berlin, Germany } \\ \text { MNHN } & =\text { Muséum national d'histoire naturelle, Paris, France }\end{array}$




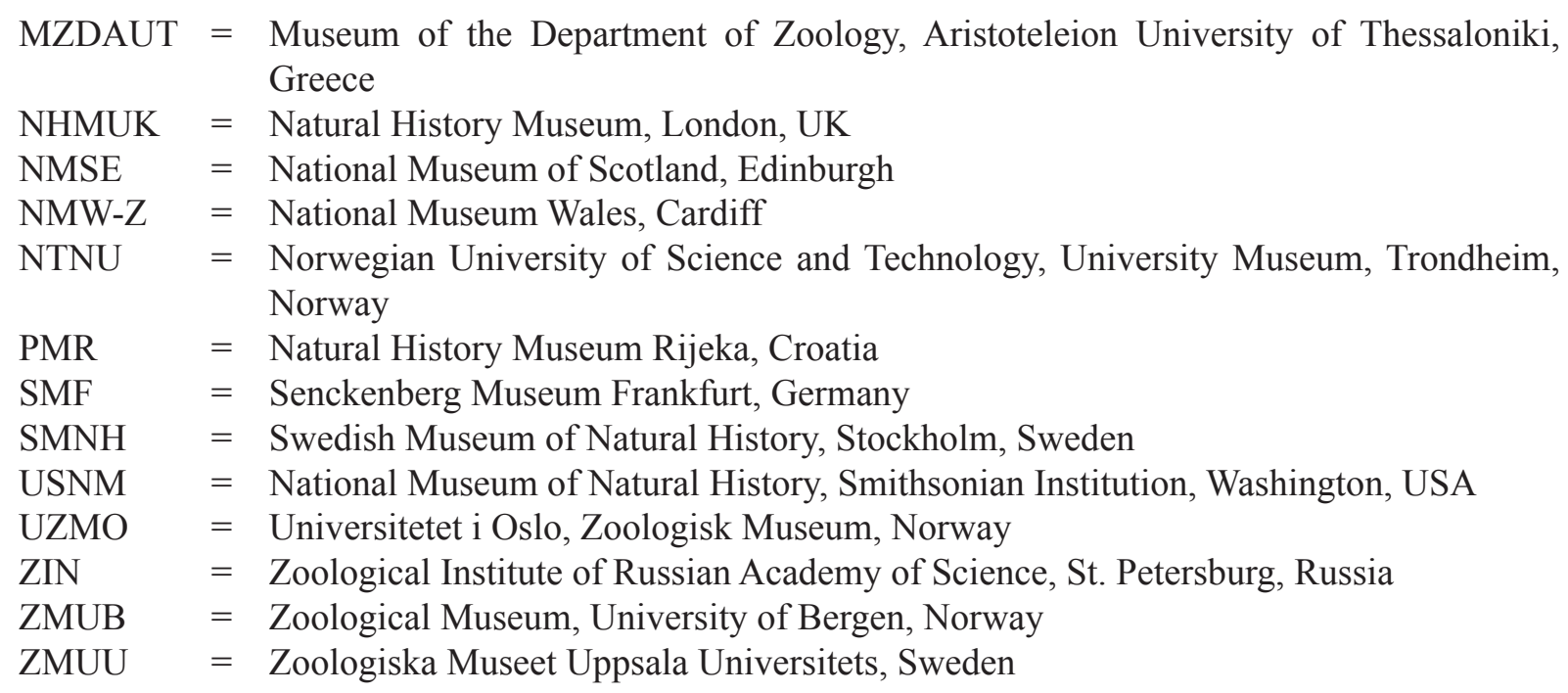

\section{Results}

Phylum Annelida Lamarck, 1809

Class Polychaeta Grube, 1850

Order Terebellida Rouse \& Fauchald, 1997

\section{Key to the families of Terebellidae sensu lato}

1. Notopodia, if present, elongate, roughly cylindrical, distally bilobed; branchiae absent; ventrum of anterior segments with paired glandular pads (Fig. 2B, D)

Polycirridae Malmgren, 1866

- Notopodia always present, short, conical, distally bi- or single lobed; branchiae usually present; development and shape of ventral glandular areas of anterior segments variable between families, but never as paired mid-ventral pads

2. Thoracic uncini acicular (Figs 1A, 7D)

Trichobranchidae Malmgren, 1866

- Thoracic uncini avicular (Fig. 1B-F)

3. Neuropodia with uncini in double rows on some segments (Fig. 6E); branchiae, if present, cirriform, arborescent or spiralled Terebellidae Johnston, 1846 sensu stricto

- Neuropodia with uncini in single rows throughout; branchiae rarely absent, always cirriform ....... 4

4. Upper lip expanded, distinctly longer than wide (Figs 3F, 4A); neuropodia poorly developed throughout, as nearly sessile ridges and distinctly low pinnules on thoracic and abdominal segments, respectively Telothelepodidae Nogueira, Fitzhugh \& Hutchings, 2013

- Upper lip short, hood-like, about as wide as long, frequently circular (Figs 3D-E, 4B-C); welldeveloped neuropodia throughout, as fleshy ridges and elongate pinnules on thoracic and abdominal segments, respectively Thelepodidae Hessle, 1917

Family Polycirridae Malmgren, 1866

Figs 1B, 2

Diagnosis (after Hutchings et al. 2021a; most important diagnostic characters highlighted in bold)

Transverse prostomium attached to dorsal surface of upper lip; basal part usually as thick horse-shoe shaped crest, eye spots absent; distal part either as another thick crest, with flaring distal lobes, with or without mid-dorsal process, or extending along upper lip until near anterior margin of lip; prostomium 

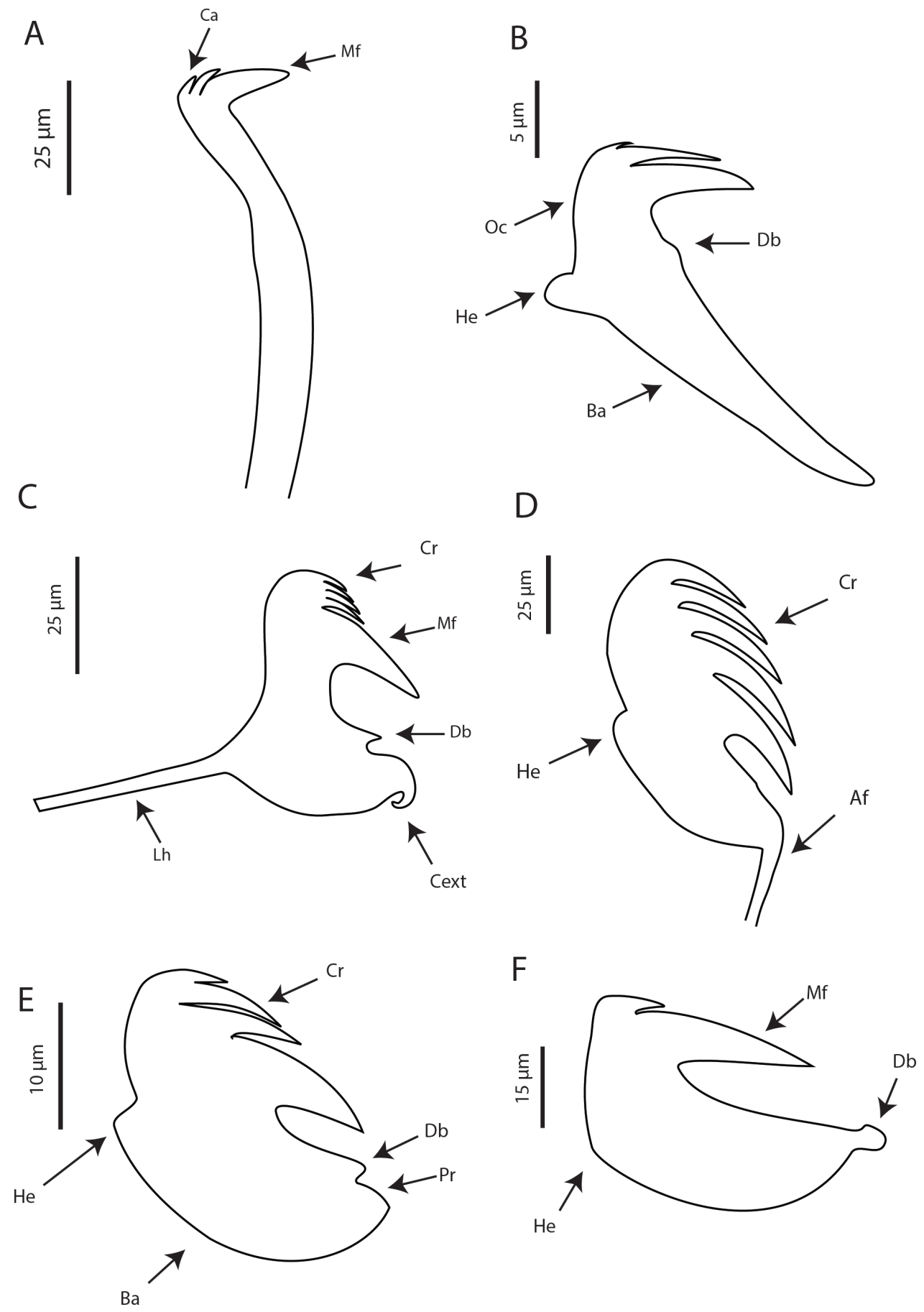

Fig. 1. Schematic illustrations of different uncini morphologies, in lateral view (following Nogueira et al. 2010). A. Terebellides sp., SG IX (SMA-BR-Terebellides-KER1). B. Polycirrus catalanensis Lavesque, Hutchings, Daffe \& Londoño-Mesa, 2020, SG XX (holotype MNHN-IA-TYPE 2007). C. Pista sauriaui Lavesque, Daffe, Londoño-Mesa \& Hutchings, 2021, SG V (paratype MNHN-IATYPE 2036). D. Lomia ramzega Lavesque, Bonifácio, Londoño-Mesa, Le Garrec \& Grall, 2017, SG XII (paratype MNHN-IA-TYPE 1791). E. Streblosoma cabiochi Lavesque, Londoño-Mesa, Daffe \& Hutchings, 2020, SG VI (holotype MNHN-IA-TYPE 2000). F. Thelepus japonicus Marenzeller, 1884, SG XVII (MNHN-IA-PNT 117). Abbreviations: $\mathrm{Af}=$ anterior filament; $\mathrm{Ba}=$ base; $\mathrm{Ca}=$ capitium; $\mathrm{Cext}=$ coma-shape extension $\mathrm{Cr}=$ crest $\mathrm{Db}=$ dorsal button; $\mathrm{He}=$ heel; $\mathrm{Lh}=$ long handle; $\mathrm{Mf}=$ main fang; Oc = occipitium; $\mathrm{Pr}=$ prow. 
frequently extending ventrally, terminating laterally to mouth (Fig. 2A-D). Buccal tentacles of two types at least, short ones thin, uniformly cylindrical, long tentacles stouter, expanded at tips to variable degrees, distally spatulate (Fig. 2B, D) or more specialised. Peristomium forming lips; lips expanded, upper lip large, frequently circular and convoluted, folded into three lobes; swollen lower lip, only midventral or cushion-like across ventrum, sometimes extending posteriorly for a few segments (Fig. 2AD). Segment I reduced, frequently only visible ventrally, sometimes completely hidden. Segment II distinctly narrower than following segments, constricting body posteriorly to "lips head"; SG II usually with rectangular or pentagonal mid-ventral shield at beginning of mid-ventral groove, sometimes extending anteriorly through SG I until near posterior margin of lower lip (Fig. 2C). Anterior segments highly glandular ventrally, frequently papillose or tessellated, with paired ventro-lateral pads separated from each other within pairs by mid-ventral groove extending from SG II-IV to posterior body (Fig. 2A-D). Branchiae absent. Notopodia, if present, from SG III (Fig. 2A-D), extending for variable number of segments, usually few; bilobed, elongate notopodia, post-chaetal lobes sometimes longer, notochaetae originating between lobes along all extension of notopodia, separating lobes from base on ventral side of notopodia (Fig. 2A-D); notochaetae winged (Fig. 2E) and/or pinnate, wings of variable width. Neuropodia, if present, located posteriorly to notopodia, frequently from posterior thoracic segments or only on abdomen; neurochaetae as acicular spines or avicular uncini, of two types, and arranged in a single row (Figs $1 \mathrm{C}, 2 \mathrm{~F}-\mathrm{G}$ ). Nephridial and genital papillae usually present, at anterior bases of all notopodia, or only at anteriormost notopodia (Fig. 2A). Pygidium smooth or with rounded ventral papilla.

\section{Remarks}

This family was previously considered as a subfamily of Terebellidae (Polycirrinae Malmgren, 1866), but was recently raised to familial level after a comprehensive phylogenetic analysis showed the monophyly of this group (Nogueira et al. 2013). Polycirridae is represented by six genera (Amaeana Hartman, 1959; Biremis Polloni, Rowe \& Teal, 1973; Enoplobranchus Verrill, 1879; Hauchiella Levinsen, 1893; Lysilla Malmgren, 1866 and Polycirrus Grube, 1850), distinguished from each other by the presence/ absence of noto- and neuropodia, and if present, the type of neurochaetae. Only Amaeana (Fig. 2A, C), Hauchiella, Lysilla and Polycirrus (Fig. 2B, D-G) are represented in European waters (Lavesque et al. 2020b) (Table 1).

\section{Main morphological characters of European species}

PARAPODIA. The parapodia of the members of this family are extremely important to separate the different genera. The genus Hauchiella is characterised by the absence of parapodia and Lysilla by the absence of neuropodia only. The neuropodia of members of Amaeana are characterised by the presence of spines, while those of Polycirrus bear avicular uncini (Figs 1B, 2F-G). Within the genus Polycirrus, the number and location of segments with notopodia and/or neuropodia are of important taxonomic value. Particularly, some species have uncini present only on abdominal segments, i.e., on segments without notopodia, and others have uncini starting before the end of the thorax, on segments bearing also notopodia.

SHAPE OF THE LIPS. As for other terebellids, polycirrids have a peristomium with well-defined upper and lower lips. The upper lip is large and can be trilobed (Fig. 2B) or with a single medial lobe (Fig. 2D). Generally, the upper lip is trilobed but the lobes differ in size and shape and lateral lobes can be reduced or well developed. The shape and the size of the lower lip is also highly variable between species. This lip can be rectangular, squared, rounded or subtriangular, swollen or not, longer than wide or wider than long (Fig. 2B-D). 

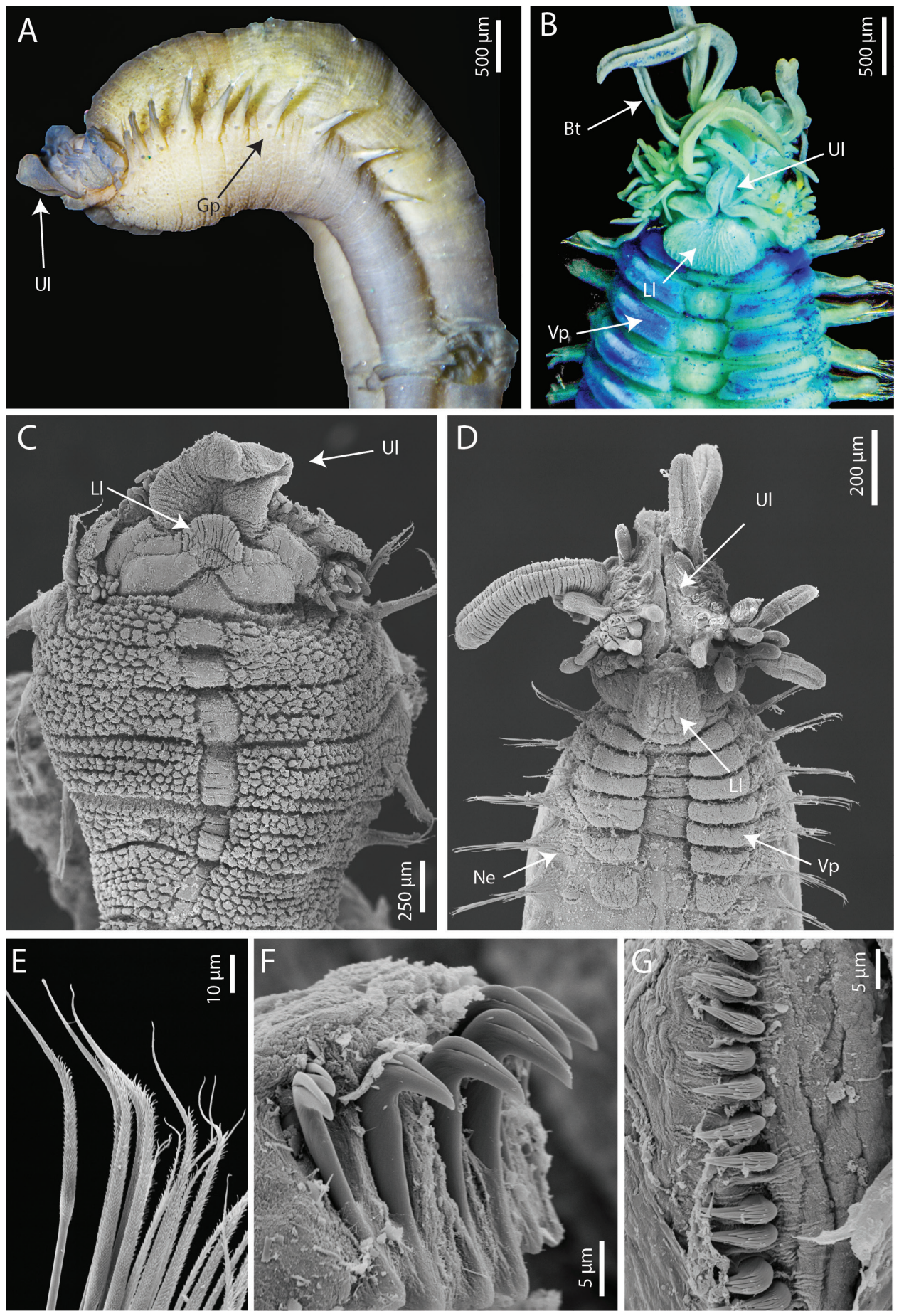

Fig. 2. Diversity of Polycirridae Malmgren, 1866. A. Amaeana gremarei Lavesque, Hutchings, Daffe \& Londoño-Mesa, 2020, anterior end, lateral view (MNHN-IA-TYPE 2006). B. Polycirrus gujanensis Lavesque, Hutchings, Daffe \& Londoño-Mesa, 2020, anterior end, ventral view (MNHN-IA-TYPE 2013). C. Amaeana gremarei, anterior end, ventral view (AM W.53111). D. Polycirrus idex Lavesque, Hutchings, Daffe \& Londoño-Mesa, 2020, anterior end, ventral view (AM W.53127). E. Polycirrus glasbyi Lavesque, Hutchings, Daffe \& Londoño-Mesa, 2020, notochaetae SG V (AM W.53118). F. Polycirrus catalanensis Lavesque, Hutchings, Daffe \& Londoño-Mesa, 2020, abdominal uncini (AM W.53113). G. Polycirrus glasbyi, thoracic uncini (AM W.53118). Abbreviations: Bt $=$ buccal tentacles; $\mathrm{Gp}=$ genital papilla; $\mathrm{Ll}=$ lower lip; $\mathrm{Ne}=$ neuropodia; $\mathrm{Ul}=$ upper lip; $\mathrm{Vp}=$ ventral pads. 


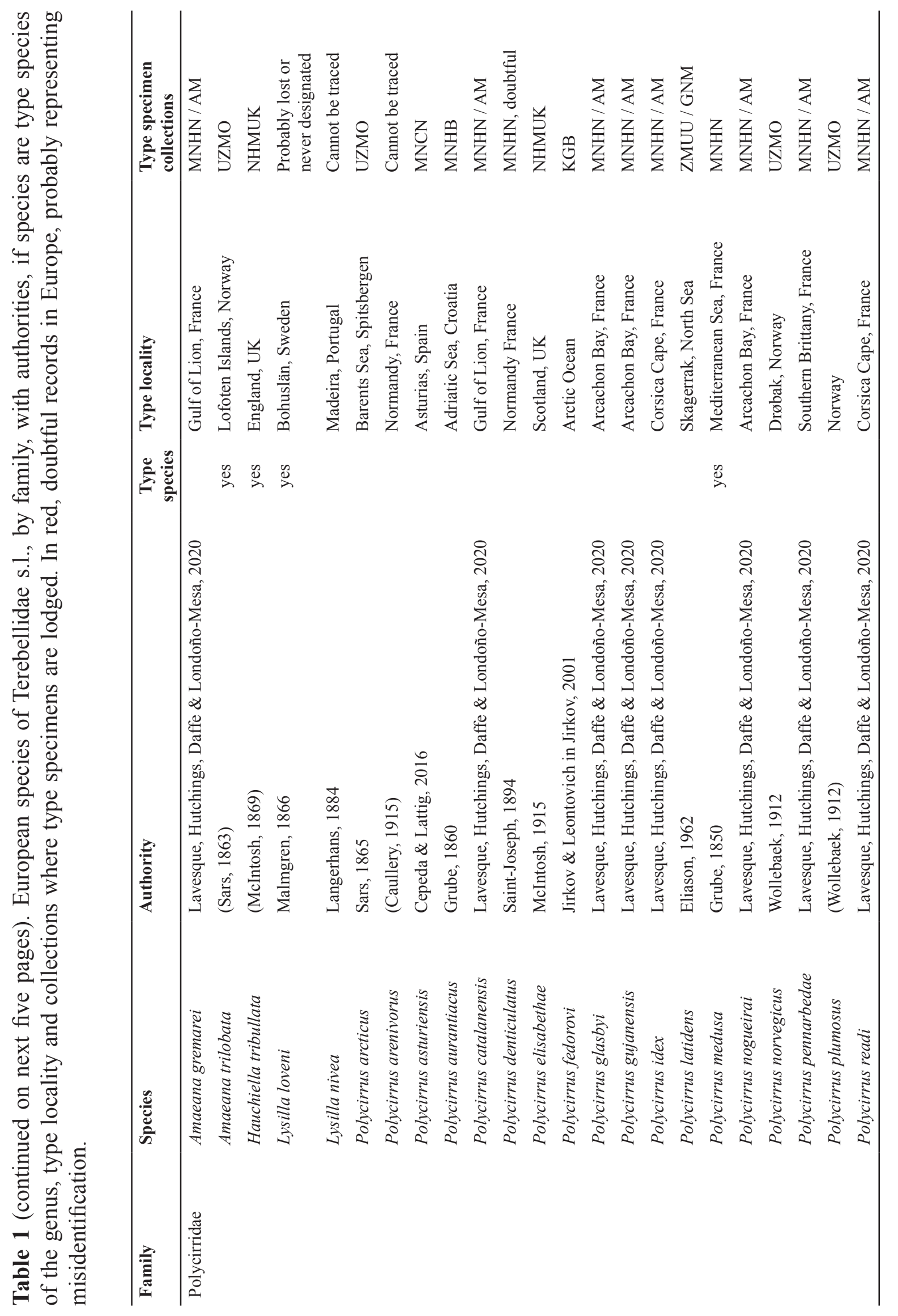




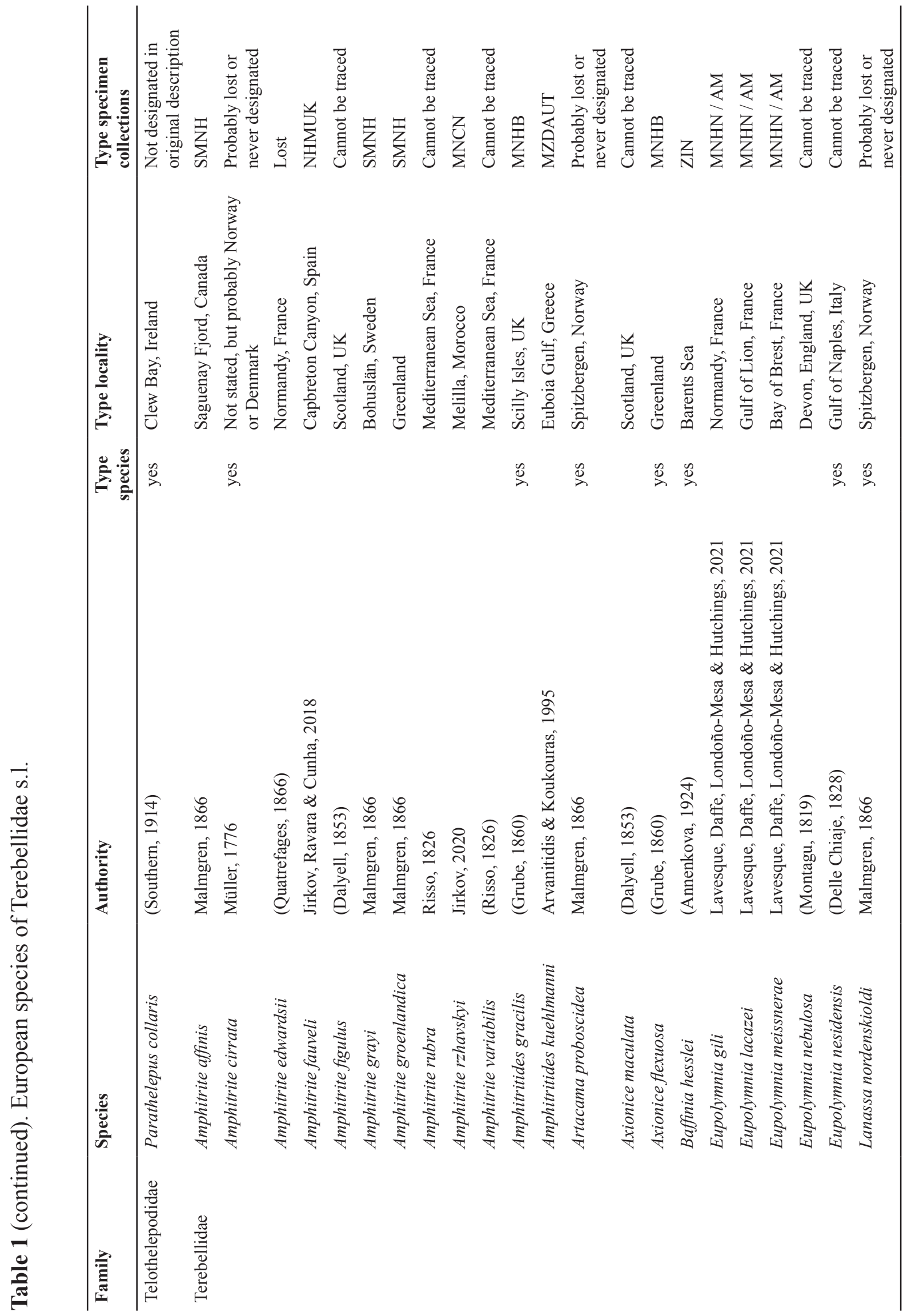




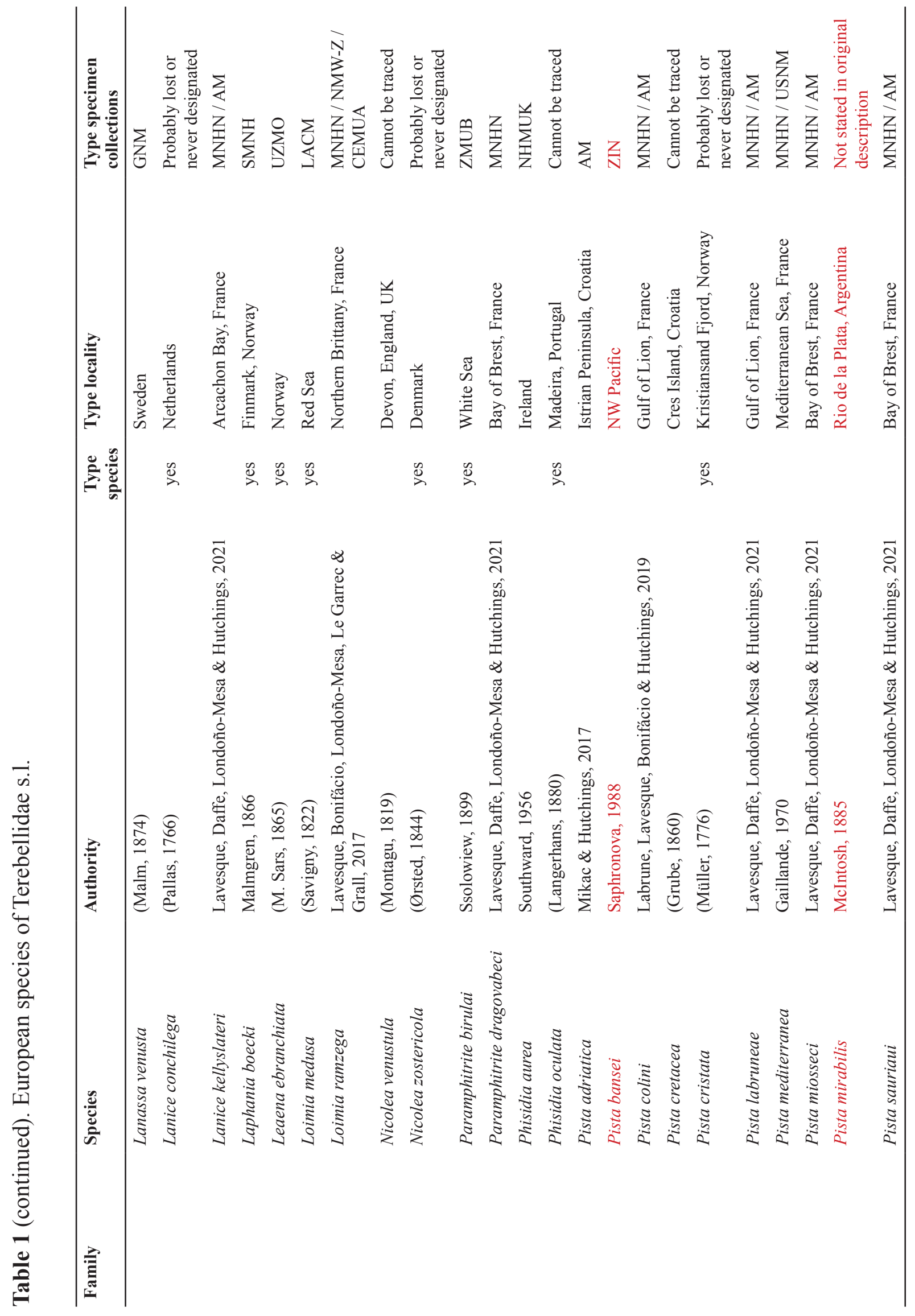




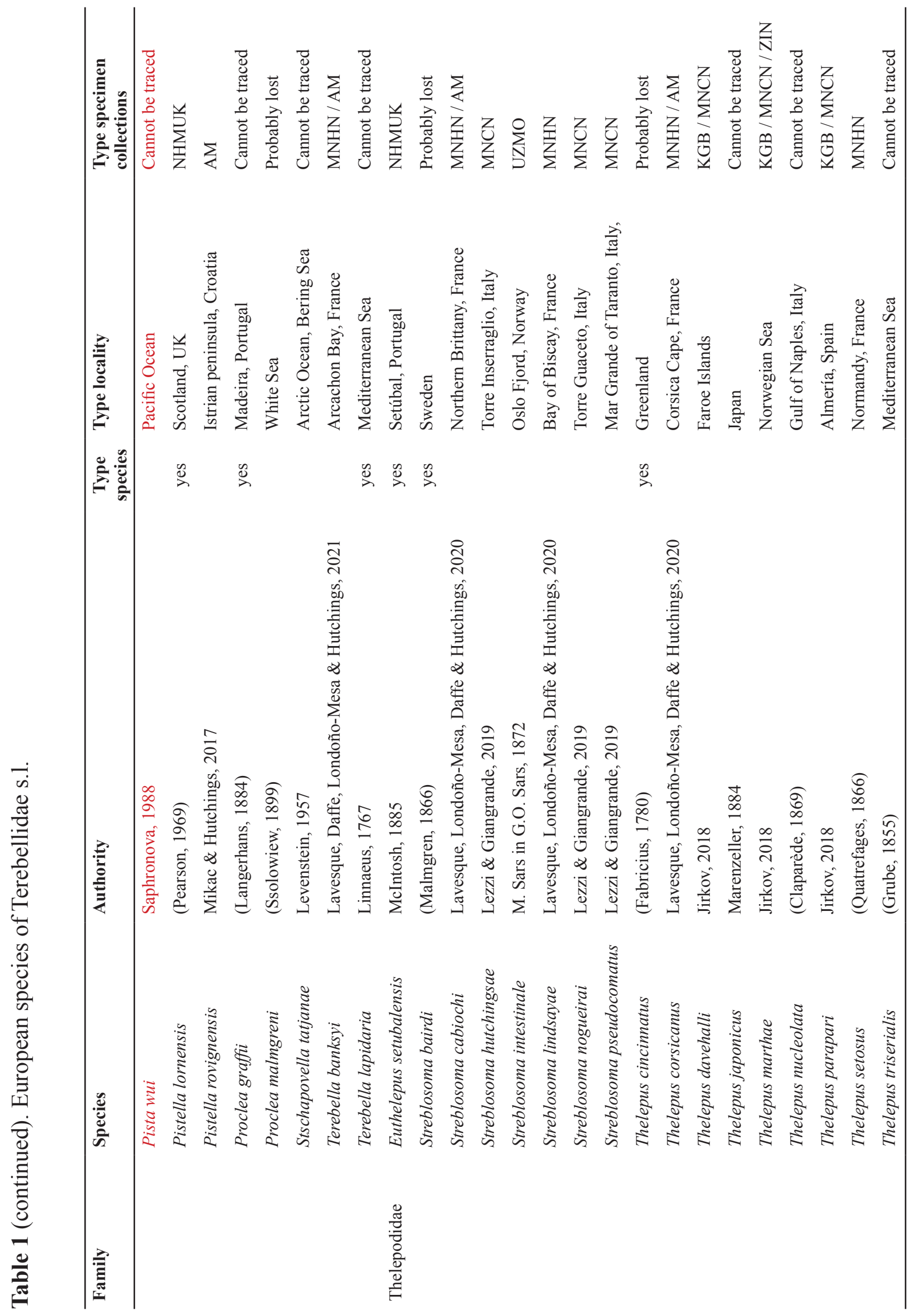




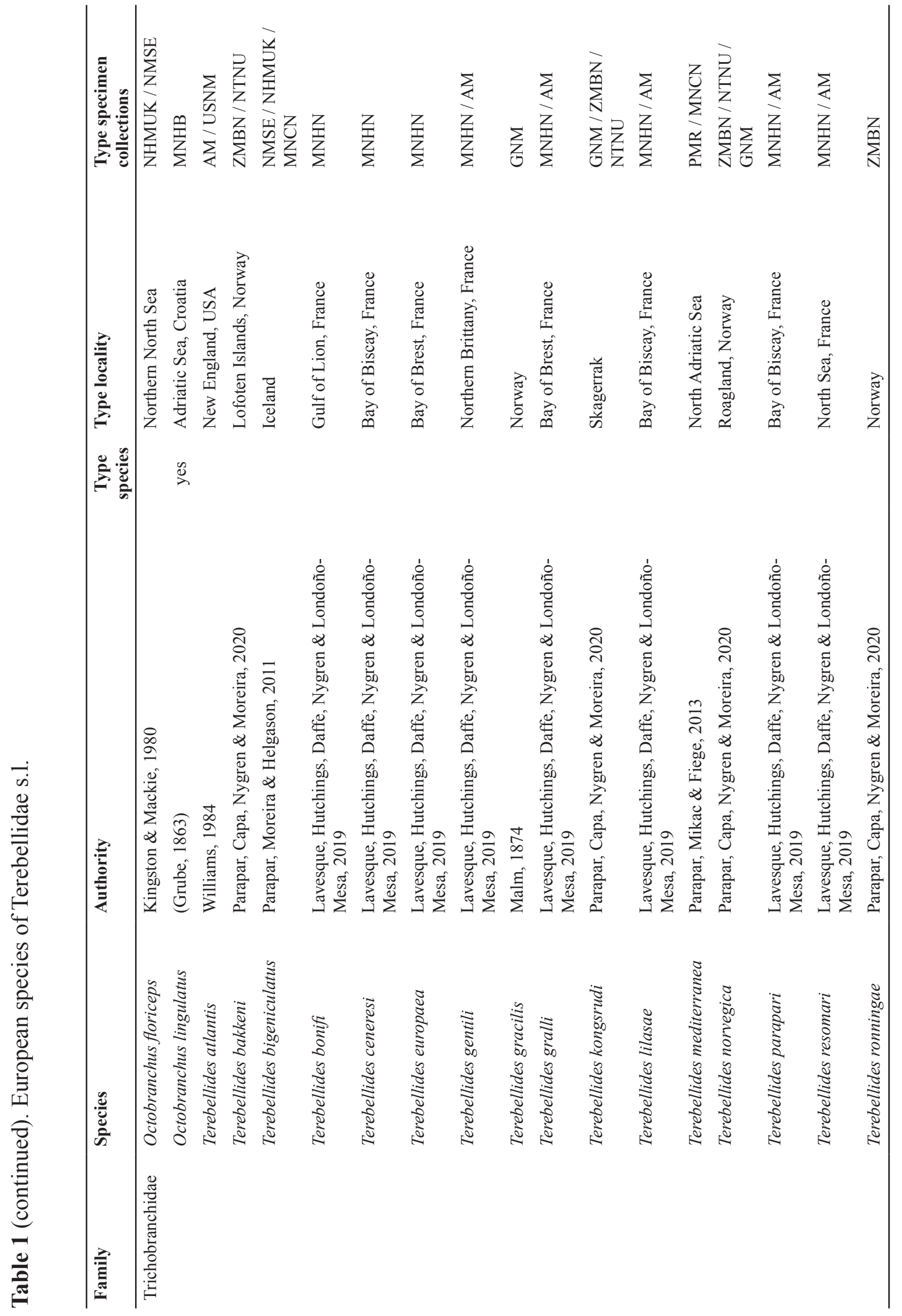




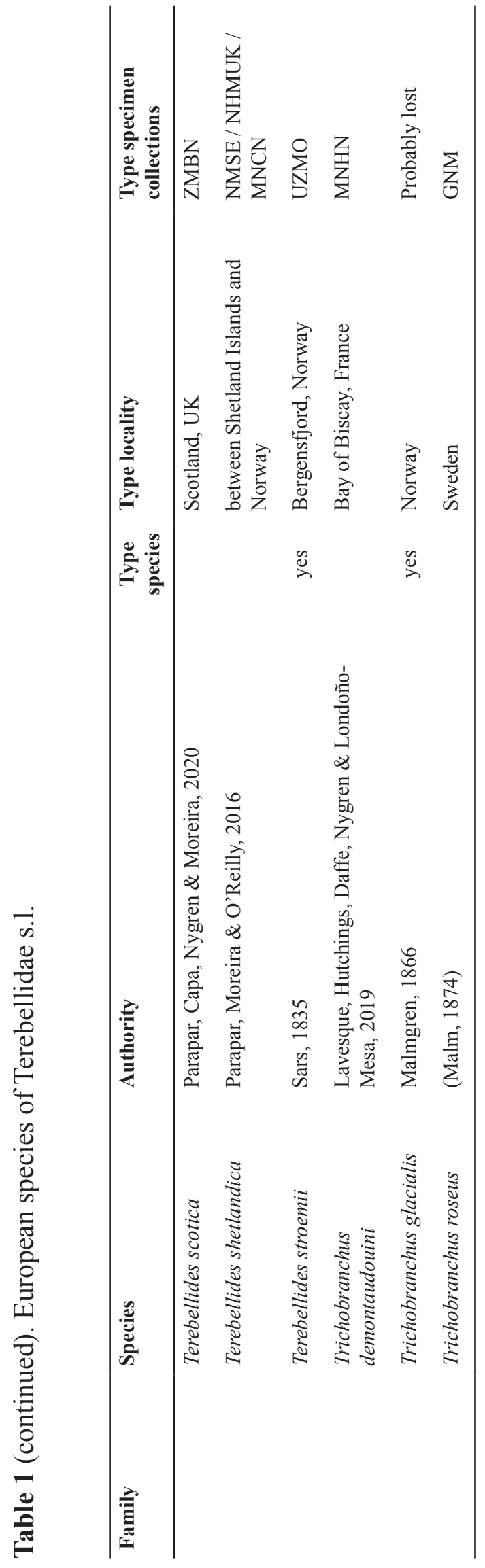


Notochaetae. Two types of notochaetae can be present: winged chaetae as for P. glasbyi (Fig. 2E) and/ or pinnate as for P. plumosus. The winged notochaetae have wings of different width which are often conspicuous under light microscope but appear hirsute under SEM (Fig. 2E).

Uncini shape and Denticulation. In Polycirrus two types of uncini are present: Type 1 with a short occipitum (back) and a straight to slightly convex base (Fig. 1B); and Type 2 with a long occipitum and a concave base (Glasby \& Hutchings 2014). To date, all described European species have Type 1 uncini. The denticulation of uncini is also helpful in separating species, with the presence (as for P. catalanensis) (Fig. 2F) or the absence (as for P. arenivorus) of a main tooth above the main fang, and the number of rows of secondary teeth.

Key to European species of Polycirridae (after Lavesque et al. 2020b)

1. Parapodia absent (no chaetae)

Hauchiella tribullata (McIntosh, 1869)

- Parapodia present

2. Only notopodia present 3 (Lysilla)

- Notopodia and neuropodia present 4

3. Notochaetae with smooth tips, 6 pairs of thoracic papillae Lysilla loveni Malmgren, 1866

- Notochaetae with plumose tips, 9 pairs of thoracic papillae Lysilla nivea Langerhans, 1884

4. Neuropodia with spines 5 (Amaeana)

- Neuropodia with avicular uncini 6 (Polycirrus)

5. Upper lip without lobe, lower lip rounded, long achaetous region

A. gremarei Lavesque, Hutchings, Daffe \& Londoño-Mesa, 2020

- Upper lip with trilobed, lower lip rectangular, short achaetous region

Amaeana trilobata (Sars, 1863)

6. With 28 or more segments with notochaetae 7

- With 22 or fewer segments with notochaetae 8

7. With 29 segments with notopodia, neuropodia from SG XII, lower lip longer than wide, uncini without a main tooth above the main fang Polycirrus arenivorus (Caullery, 1915)

- With 46 segments with notopodia, neuropodia from SG XIV, lower lip longer than wide, uncini with a main tooth above the main fang Polycirrus aurantiacus Grube, 1860

- With 28 segments with notopodia, neuropodia from SG XV, lower lip wider than long, uncini with a main tooth above the main fang

Polycirrus gujanensis Lavesque, Hutchings, Daffe \& Londoño-Mesa, 2020

8. Neuropodia beginning before SG VIII 9

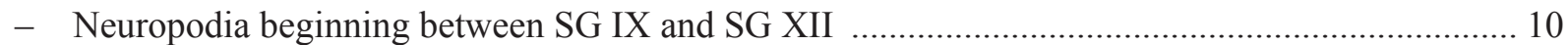

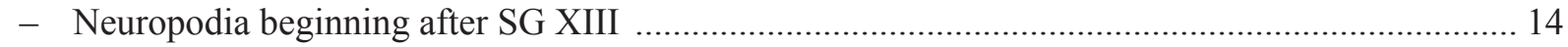

9. Upper lip trilobed, lower lip wider than long, uncini with 2 rows of teeth above the main tooth ....... Polycirrus asturiensis Cepeda \& Lattig, 2016

- Upper lip with single medial lobe, lower lip longer than wide, uncini with 1 row of teeth above the main tooth Polycirrus idex Lavesque, Hutchings, Daffe \& Londoño-Mesa, 2020b 
10. Uncini without a main tooth about the main fang Polycirrus norvegicus Wollebaek, 1912

- Uncini with a main tooth about the main fang

11. Lower lip subtriangular, pointed towards mouth 12

- Lower lip oval or oblong

12. With 12 or 13 segments with notopodia, lower lip longer than wide

Polycirrus denticulatus Saint-Joseph, 1894

- With 16 segments with notopodia, lower lip wider than long

Polycirrus elisabethae McIntosh, 1915

13. With 18 or more segments with notopodia, lower lip oval, ventro-lateral pads not separated by a large mid-ventral groove

Polycirrus glasbyi Lavesque, Hutchings, Daffe \& Londoño-Mesa, 2020

- Fewer than 18 segments with notopodia, lower lip oblong, ventro-lateral pads separated by a large midventral groove

Polycirrus readi Lavesque, Hutchings, Daffe \& Londoño-Mesa, 2020

14. With 16 or more segments with notopodia

- Fewer than 16 segments with notopodia

15. Neuropodia beginning from SG XIV-XVI

- Neuropodia beginning from SG XVIII-XX Polycirrus plumosus (Wollebaek, 1912)

16. Upper lip elongated, uncini with a main tooth above the main fang, ventro-lateral pads well developed

Polycirrus nogueirai Lavesque, Hutchings, Daffe \& Londoño-Mesa, 2020

- Upper lip semicircular, uncini without a main tooth above the main fang, ventro-lateral pads poorly defined

17. Neuropodia beginning from SG XIV, uncini with four teeth above the main fang arranged in single vertical series; lower lip large, shield-like, wider than long Polycirrus latidens Eliason, 1962

- Neuropodia beginning from SG XV or after, secondary teeth of uncini not as above 18

18. Upper lip trilobed, lower lip subtriangular pointed toward mouth

- Upper lip with a single median lobe, lower lip not subtriangular

Polycirrus medusa Grube, 1850

19. Upper lip with thick medial lobe, uncini with two small lateral teeth above the main tooth, lower lip rectangular longer than wide

Polycirrus catalanensis Lavesque, Hutchings, Daffe \& Londoño-Mesa, 2020

- Upper lip with elongated triangular medial lobe, uncini with two rows of teeth above the main tooth, lower lip oval and wider than long

P. pennarbedae Lavesque, Hutchings, Daffe \& Londoño-Mesa, 2020 
Family Telothelepodidae Nogueira, Fitzhugh \& Hutchings, 2013

Figs 3-4

Diagnosis (after Nogueira et al. 2018; Hutchings et al. 2021a, most important diagnostic characters highlighted in bold)

Transverse prostomium attached to dorsal surface of upper lip; basal part as thick crest, eyespots frequently present in one pair of dorso-lateral clusters, each with several rows of eyespots (Fig. 3A); distal part at base of upper lip, frequently with low or erect mid-dorsal tongue-like process, fused to upper lip at variable degrees, with free distal lobe(s), or free from the base. Buccal tentacles of two types, short ones thin, uniformly cylindrical, long tentacles stouter and expanded at tips, slightly spatulate (Figs 3A-B, F, 4A). Peristomium forming lips and continuing dorsally at least for short extension, with dorso-lateral nuchal organs at margin with prostomium; lips expanded, upper lip distinctly elongate and narrow, undulated to convoluted; swollen lower lip extending across ventrum, cushion-like or segment-like, frequently deeply grooved (Figs 3A-B, 4A). Either SG I or SG II reduced, not forming complete ring in many species. Anterior segments glandular ventrally, smooth, discrete shields absent and frequently with glandular regions poorly developed in comparison to other families of Terebellidae s.l.; mid-ventral groove frequently extending from anterior segments. Two pairs of cirriform branchiae on SG II-III, each pair with simple thin, curled and relatively short filaments progressively tapering to tips (Figs 3A, 4A), originating from raised crests on anterior margins of SG II and III, or from specialised, apparently glandular, dorso-lateral cushion-like pads occupying from anterior margins to level of posterior bases of notopodia of those segments. Notopodia beginning from SG II or III, usually SG III, extending for at least 15 segments; notopodia as short cones, notochaetae originating from central core on top, distal lobes absent; notochaetae winged, sometimes with bulbous head and alimbate tips (bayonet-like chaetae), at least in anterior row of anterior thoracic segments. Neuropodia beginning posteriorly to notopodia, usually around SG VIII-XII; neuropodia in conjunction with notopodia as sessile tori, as distinctly low pinnules after notopodia terminate; neurochaetae in single row, as avicular uncini about as long as high, with short triangular heel directed posteriorly, wide and slightly curved base, and dorsal button near midlength of uncini, but closer to anterior margin (Fig. 4E). Nephridial and genital papillae, if conspicuous, on SG V-VII, posterior to bases of notopodia.

\section{Remarks}

This recent family was described by Nogueira et al. (2013) after conducting a comprehensive phylogenetic analysis. The members of this family were previously considered as Thelepodidae but differ in having a narrow and elongate upper lip, poorly developed neuropodia and anterior segments less glandular ventrally than in other thelepodids. In European waters, this family is represented by a single species, Parathelepus collaris (Figs 3A-B, 4A, E; Table 1), characterised by an expanded, tongue-like upper lip, by neuropodia poorly developed and beginning from SG XI.

\section{Family Thelepodidae Hessle, 1917 Figs 1F, 3-4}

Diagnosis (after Hutchings et al. 2021a, most important diagnostic characters highlighted in bold)

Transverse prostomium attached to dorsal surface of upper lip; basal part as thick crest, eyespots frequently present, in short lateral rows, or extending transversely across basal part of prostomium, usually progressively more spaced towards dorsal mid-line, with mid-dorsal gap or not; distal part of base of upper lip short, from nearly indistinct to shelf-like. Buccal tentacles all uniformly thin and cylindrical, to slightly spatulate distally (Figs 3D, F, 4B). Peristomium forming lips, sometimes also complete annulation, with dorso-lateral nuchal organs as ciliated grooves; lips expanded, relatively short 
upper lip, hood-like, about as long as wide; swollen, button-like, mid-ventral lower lip (Figs 3D, F, 4B-C). Segment 1 usually present all around, frequently with ventral lobe marginal to mouth (Figs 3D, F, 4B-C); SG II typically with anterior margin as protruding crest, at least ventrally (Figs 3D-E, 4B-C); lobes on following anterior segments sometimes present. Anterior segments highly glandular ventrally, smooth to highly corrugated between neuropodia within pairs, discrete shields absent (Figs 3D F, 4B); mid-ventral groove frequently extending from anterior segments with notopodia. Two to three pairs of branchiae, on SG II-III or II-IV, each pair with simple thin, curled and relatively short filaments progressively tapering to tips (Figs 3C, E, 4C), leaving mid-dorsal gap or not between filaments within pairs; branchial filaments originating directly from the body wall or from specialised dorsolateral cushion-like pads. Notopodia beginning on SG II-III, usually extending to mid-body, at least, sometimes until near posterior end; cylindrical to rectangular, distally bilobed notopodia, notochaetae originating between lobes; most taxa with winged notochaetae only, with wings of variable width (Fig. 4D), distally serrated notochaetae sometimes also present; bayonet-like and pinnate chaetae both absent. Neuropodia beginning posteriorly to notopodia, on SG IV-VI, typically on SG V; neuropodia in conjunction with notopodia as fleshy, swollen ridges, as raised rectangular to cylindrical pinnules after notopodia terminate; neurochaetae as avicular uncini frequently longer than high, with short triangular heel directed posteriorly, distinctly curved and wide base, and dorsal button near anterior margin of uncini, or within anterior third of distance between anterior margin of uncini and base of main fang (Fig. 4F). Nephridial and genital papillae usually present, on SG IV-VII, posterior to bases of notopodia or between parapodial lobes (Fig. 3C).

\section{Remarks}

A comprehensive phylogenetic analysis conducted by Nogueira et al. (2013) permitted the elevation of the previous Thelepodinae subfamily to Thelepodidae family level, as they represented a separate clade from other terebellids. This family is represented in European waters by three genera Euthelepus McIntosh, 1885 (a single species), Streblosoma Sars, 1872 (seven species) and Thelepus Leuckart, 1849 (nine species) (Table 1). Among these species, Thelepus japonicus Marenzeller, 1884, native from Japan, is considered as a non-indigeneous species in French waters, probably introduced with oyster transfers (Lavesque et al. 2020a) (Fig. 3C).

\section{Main morphological characters of European species}

Branchiae. Both in Thelepus and Streblosoma genera, the number of pairs of branchiae varies between two (e.g., Streblosoma lindsayae or Thelepus nucleolata) and three (e.g., Streblosoma hutchingsae or Thelepus setosus). Branchiae in Thelepodidae are always cirriform (Figs 3C, E, 4C) but the number of branchial filaments varies among the species with for example 5-10 filaments on the second and third pairs of branchiae for Streblosoma cabiochi (Fig. 3E) and only three or less filaments for Streblosoma intestinale. Finally, the size of the medial dorsal gap separating the pairs of branchiae is a good diagnostic character. This gap is for example inconspicuous for T. parapari and wide for Thelepus cincinnatus (Nogueira 2019).

PRESENCE OF EYESPOTS. The eyespots are very useful in differentiating species of Streblosoma and Thelepus for which they can be absent (e.g., Thelepus davehalli or Streblosoma hutchingsae) or present (e.g.m Thelepus corsicanus or Streblosoma nogueirai). Also, the arrangement of the eyespots, if in a continuous line, or leaving a medial gap is of taxonomic importance (Nogueira et al. 2010).

START AND EXTENSION OF NOTOPODIA. The segment with the first appearance of notopodia permits the discrimination between the genus Streblosoma, for which notopodia begin on the second segment, and Euthelepus and Thelepus for which it begins on the third segment. These notopodia also extend for a variable number of segments, sometimes present only on the anterior half of the body (e.g., T. corsicanus) or present until the end of the body (T. japonicus). 

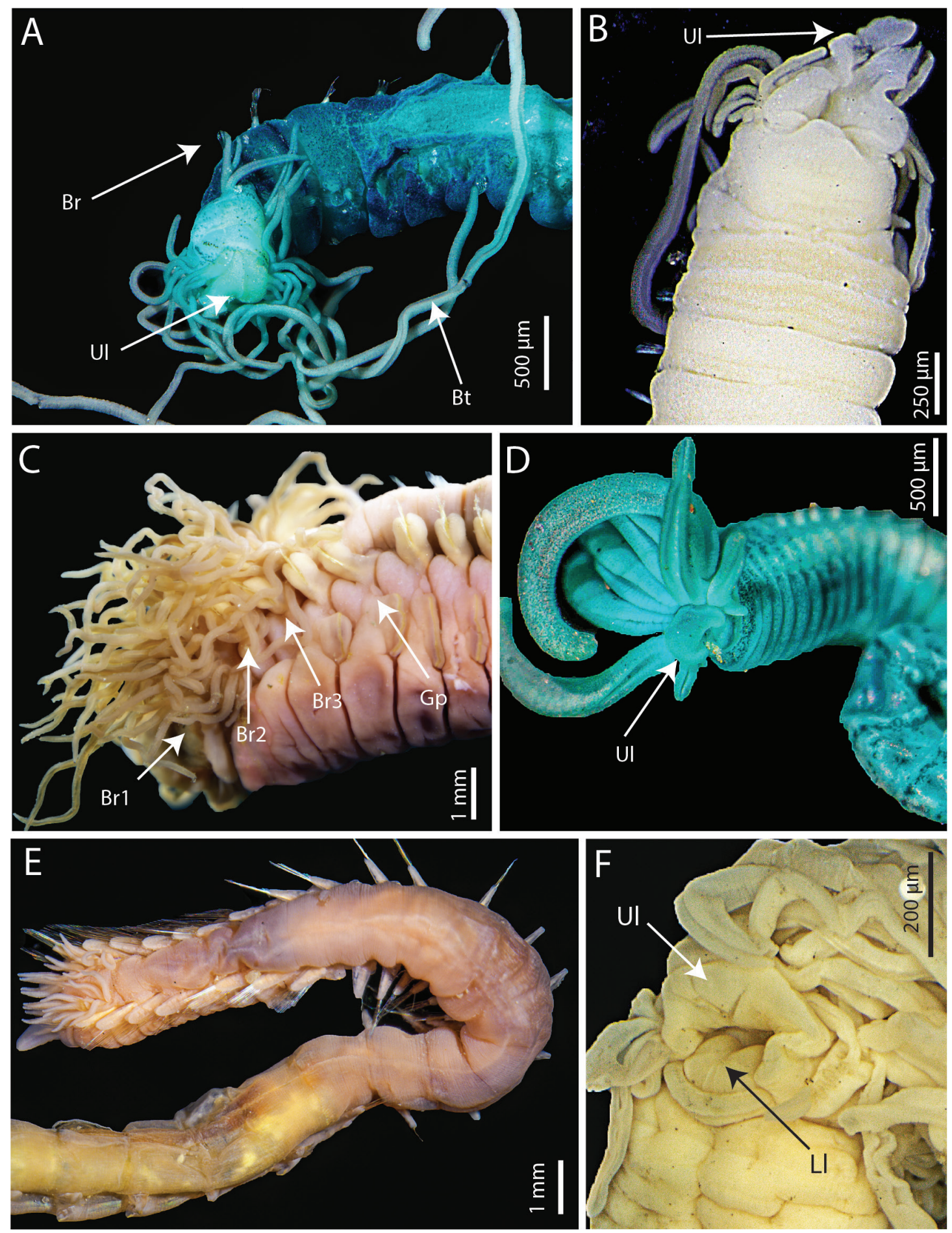

Fig. 3. Diversity of Telothelepodidae Nogueira, Fitzhugh \& Hutchings, 2013 and Thelepodidae Hessle, 1917. A. Parathelepus collaris (Southern, 1914), anterior end, frontal view (AM W.53063). B. Parathelepus collaris, anterior end, ventral view (NHMUK ANEA 1983.1696). C. Thelepus japonicus Marenzeller, 1884, anterior end, lateral view (AM W.53073). D. Thelepus corsicanus Lavesque, Londoño-Mesa, Daffe \& Hutchings, 2020, anterior end, frontal view (AM W.53068). E. Streblosoma cabiochi Lavesque, Londoño-Mesa, Daffe \& Hutchings, 2020, anterior end, dorsal view (MNHN-IATYPE 2000). F. Thelepus japonicus, anterior end, ventral view (MNHN-IA-PNT 117). Abbreviations: $\mathrm{Br}=$ Branchiae; $\mathrm{Bt}=$ Buccal tentacles; $\mathrm{Gp}=$ genital papillae; $\mathrm{Ll}=$ Lower lip; $\mathrm{Ul}=$ Upper lip. 

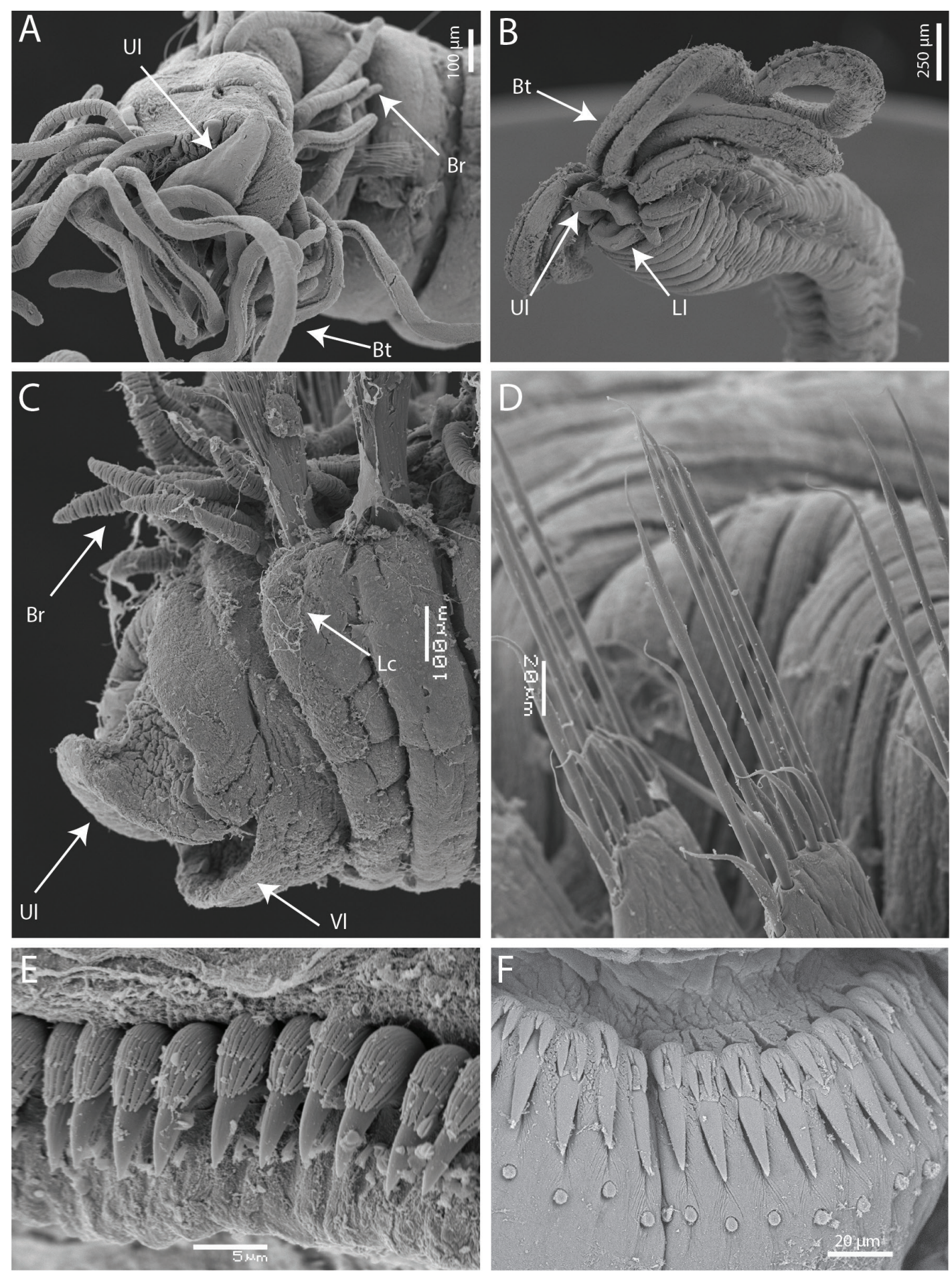

Fig. 4. Diversity of Telothelepodidae Nogueira, Fitzhugh \& Hutchings, 2013 and Thelepodidae Hessle, 1917, SEM. A. Parathelepus collaris (Southern, 1914), anterior end, frontal view (AM W.53063). B. Thelepus corsicanus Lavesque, Londoño-Mesa, Daffe \& Hutchings, 2020, anterior end, latero-frontal view (AM W.53069). C. Streblosoma cabiochi Lavesque, Londoño-Mesa, Daffe \& Hutchings, 2020, anterior end, lateral view (AM W.53066). D. Thelepus corsicanus, thoracic notochaetae (AM W.53069). E. Parathelepus collaris, abdominal uncini, (AM W.53063). F. Thelepus japonicus Marenzeller, 1884, abdominal uncini, SG48. (SMA-NL-Thele08). Abbreviations: $\mathrm{Br}=$ Branchiae; $\mathrm{Bt}=$ Buccal tentacles; $\mathrm{Lc}=$ lateral crest; $\mathrm{Ll}=$ Lower lip; $\mathrm{Vl}=$ Ventral lobe of SG I. 
SHAPE OF NEUROPODIA AND UNCINI. In most of the species, the uncini start on SGV which could correspond to $\mathrm{CH} 3$ (as in Thelepus) or CH4 (as in Streblosoma). The uncini are arranged habitually in single rows but some have uncini forming loops (C-shaped arrangement) from mid thorax onwards. This last character is found for example in S. nogueirai. Between species, the uncini differ in the development of the prow (e.g., well developed in T. triserialis), the shape of the base (e.g., strongly curved in S. cabiochi), the position of the dorsal button (e.g., far from anterior margin in $S$. bairdi or in a terminal position for T. japonicus (Fig. 1F) and number of secondary of teeth.

CREst And LATERAL LOBEs. The presence of lateral lobes on SG II-IV allows the separation of the genus Euthelepus from other genera of the family. The presence of lateral crests on SG II (= thick anterior margin) is an important character within the Streblosoma genus. For example, S. cabiochi has a very low crest on SG II (Fig. 4C) while S. bairdi has a protruding crest (Nogueira 2019).

Key to European species of Thelopodidae (after Lavesque et al. 2020a)

1. Notopodia from SG II (i.e., first branchiferous segment), start of uncini from $\mathrm{CH} 4$ 2 (Streblosoma)

- Notopodia from SG III (i.e., second branchiferous segment), start of uncini from CH3 8

2. Two pairs of branchiae

Streblosoma lindsayae Lavesque, Londoño-Mesa, Daffe \& Hutchings, 2020

- Three pairs of branchiae 3

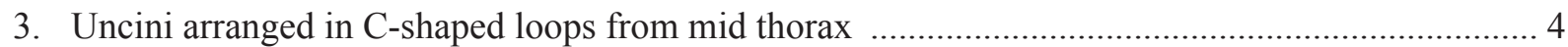

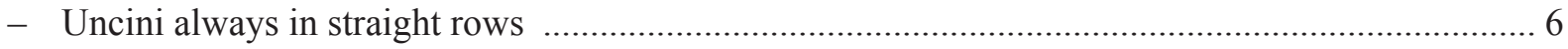

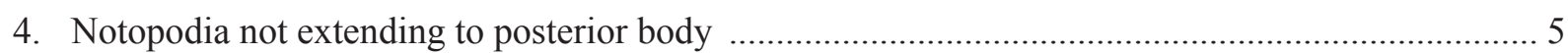

- Notopodia until posterior body ..................Streblosoma pseudocomatus Lezzi \& Giangrande, 2019

5. Eyespots absent ........................................... Streblosoma hutchingsae Lezzi \& Giangrande, 2019

- Eyespots present ................................................. Streblosoma nogueirai Lezzi \& Giangrande, 2019

6- Branchiae on SG III and SG IV with 3 or less filaments on each side

Streblosoma intestinale M. Sars in G.O. Sars, 1872

- Branchiae on SG III and SG IV with 5-10 filaments on each side

7. Absence of prostomial process, presence of lateral crest on SG II, absence of branchial cushion .... Streblosoma cabiochi Lavesque, Londoño-Mesa, Daffe \& Hutchings, 2020

- Presence of prostomial process, absence of lateral crest on SG II, presence of branchial cushion Streblosoma bairdi (Malmgren, 1866)

8. Lateral lobes on SG II-IV Euthelepus setubalensis McIntosh, 1885

- Lateral lobes on SG I only 9 (Thelepus)

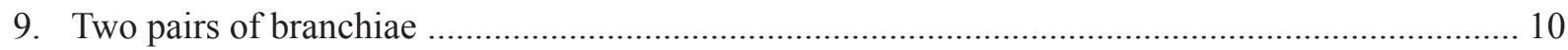

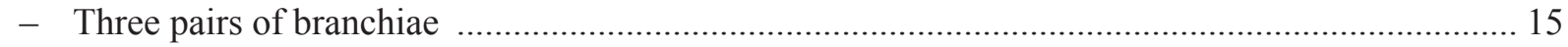

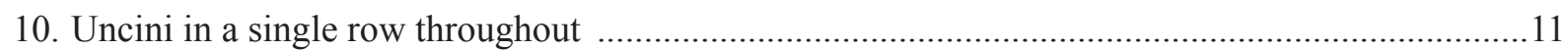

- Uncini in loops from SG XIV ............................................. Thelepus nucleolata (Claparède, 1870)

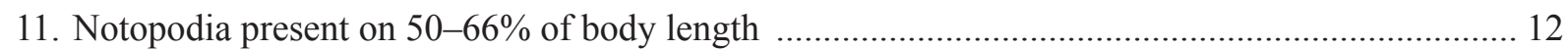

- Notopodia present on at least 90\% of body length ................................................................... 13 
12. Eyespots absent Thelepus davehalli Jirkov, 2018

- Eyespots present Thelepus corsicanus Lavesque, Londoño-Mesa, Daffe \& Hutchings, 2020

13. Uncini of $\mathrm{CH} 1$ with one tooth above main fang 14

- Uncini of $\mathrm{CH} 1$ with two teeth above main fang Thelepus parapari Jirkov, 2018

14. Eyespots present Thelepus cincinnatus (Fabricius, 1780)

- Eyespots absent Thelepus marthae Jirkov, 2018

15. Prow of uncini well developed; notch between the prow and dorsal button of the uncini well marked Thelepus triserialis (Grube, 1855)

- Prow of uncini poorly developed; notch between the prow and dorsal button of the uncini poorly marked

16. Notopodia present on about $60 \%$ of the body length Thelepus setosus (Quatrefages, 1866)

- Notopodia present until end of the body length Thelepus japonicus Marenzeller, 1884

Family Terebellidae Johnston, 1846 (sensu stricto)

Figs $1 \mathrm{C}-\mathrm{D}, 5-6$

Diagnosis (after Hutchings et al. 2021a, most important diagnostic characters highlighted in bold)

Transverse prostomium attached to dorsal surface of upper lip; basal part as thick crest, eyespots frequently present (Fig. 5B), in short rows at each lateral sides, or extending transversely across basal part of prostomium. Buccal tentacles all usually uniformly cylindrical. Peristomium usually forming lips only; lips expanded, relatively short upper lip, hood-like, about as long as wide; swollen, usually button-like and mid-ventral lower lip. Segment I terminating laterally to ventro-laterally, partially fused to expanded lower lip, or developed, forming lobes of variable extension and position. Lobes on anterior segments frequently present, of variable length, sometimes extending to SGV-VII (Figs 5B-D, 6AD). Anterior segments highly glandular ventrally, with discrete, smooth to corrugated, rectangular to trapezoidal mid-ventral shields extending from anterior segments until termination of notopodia, or near it; mid-ventral groove extending from termination of mid-ventral shields. Two to three pairs of branchiae usually present (Figs 5A-D, 6A-D), but three genera have a single pair and several are abranchiate; branchial filaments originating all together from single point on body wall, on either side of branchiferous segments, unbranched, or, more frequently, originating from conspicuous main stalk on either side of pair, branching from one to several levels, in plumose (spiraled), dichotomous, pectinate or arborescent arrangement. Notopodia beginning on SGII-V, SGIV in most genera, usually extending to mid-body, around SGXX, but sometimes present on fewer segments or extending more posteriorly for variable extension, rarely until near posterior end; first pairs of notopodia inserted dorso-laterally, progressively more laterally, then vertically aligned; cylindrical to rectangular notopodia. Notochaetae originating from central core on top, distal lobes absent; notochaetae distally winged, wings of variable length and width, or serrate, sometimes with wings at midlength, basally to a serrated blade; some more specialised types of notochaetae may be present (Fig. 5E-G). Neuropodia beginning posteriorly to notopodia, on SGV-IX, usually on SGV; neuropodia in conjunction with notopodia as low, sessile ridges, sometimes continuing posteriorly until pygidium, but most taxa with rectangular to cylindrical or foliaceous neuropodial pinnules after notopodia terminate; neurochaetae as avicular uncini usually as long as high, with short triangular heel directed posteriorly, slightly curved and wide base, and dorsal button (Figs 1C-D, 6E-F); uncini arranged in double rows (Fig. 6E) from around SGXI usually until termination of notopodia, but several genera with double rows. 


\section{Remarks}

In European waters, the Terebellidae s.s. are represented by 19 genera and 44 species (Table 1). Four genera are represented only by a single species: Artacama Malmgren, 1866; Baffinia Wesenberg-Lund, 1950; Laphania Malmgren, 1866; Leaena Malmgren, 1866 and Stschapovella Levenstein, 1957. Eleven of them are represented by two European species each: Amphitritides Augener, 1922; Axionice Malmgren, 1866; Lanassa Malmgren, 1866; Lanice Malmgren, 1866; Loimia Malmgren, 1866; Nicolea Malmgren, 1866; Paramphitrite Holthe, 1976; Phisidia Saint-Joseph, 1894; Pistella Hartmann-Schröder, 1996; Proclea Saint-Joseph, 1894 and Terebella Linnaeus, 1767 (Lavesque et al. 2021). The genus Eupolymnia Verrill, 1900 is represented by four species and the two most diverse European genera are Amphitrite Müller, 1771, with ten species, and Pista Malmgren, 1866 with eleven (Lavesque et al. 2021). In our recent paper focusing on French Terebellidae s.s. we have confirmed the synonymy of Neoamphitrite with Amphitrite, as suggested by several authors (Jirkov 2020; Hutchings et al. 2021a). In contrast, we consider that Amphitritides, Lanice Loimia and Paramphitrite are still valid genera (Read \& Fauchald 2021), contrary to what was proposed by Jirkov (2020) (see details in Lavesque et al. 2021).

\section{Main morphological characters of European species}

BRANCHIAE. The number and shape of branchiae are very important to separate species of Terebellidae s.s. Typically, species 2-3 pairs of branchiae are present on SG II-III or II-IV, but members of some genera, as for Polycirridae, completely lack branchiae: Baffinia, Lanassa, Laphania, Leaena, Phisidia and Proclea. Terebella banksyi is characterised by having branchiae on discontinuous segments: SG II-III and V (Fig. 5D). Generally branchiae are branching (dichotomous or arborescent), originating dorsolaterally from a main stalk (Figs 5A-D, 6A-D) or a single point on body wall, but some species have multiple unbranching branchial filaments, like Amphitrite cirrata or A. rzhavskyi. The presence or absence and the size of the branchial stem is important, like in Eupolymnia (Figs 5A-B, 6D).

LoBEs. Genera of Terebellidae s.s. are distinguished from each other by the presence (or absence) and morphology of anterior lobes, usually positioned laterally. These structures are flaps of tissues covering at least part of the preceding segment (Nogueira et al. 2010) (Figs 5B-C, 6A-D). They can be absent, as in Nicolea or Terebella, narrow, as in Paramphitrite birulai or large, as in Lanice and Eupolymnia (Fig. $5 \mathrm{~A}-\mathrm{C}$ ) and they also vary significantly in morphology and position, from ventral to dorso-lateral (Figs 5B-C, 6A-D).

Nephridial and genital papillae. Terebellids are characterised by the presence of papillae situated close to the notopodia or between parapodial lobes. The nephridial papillae occur from SG III-V, while genital papillae are present from SG VI onwards and are prominent only when the animals are mature (Fig. 5C-D, 6C). When they are visible, the morphology and the number of these papillae and their number permit the discrimination of species, as for Amphitrite or Terebella for example.

Notopodia AND NEUROPODIA. Terebellidae s.s. differ by the number of pairs of notopodia, the segment on which notopodia and neuropodia start and the morphology of both noto- and neurochaetae. Usually, notochaetae are present on 17 segments, beginning from SG IV, but several exceptions exist as for example for Lanassa $(\mathrm{n}<15)$ or Terebella $(\mathrm{n}>25$, often present to the pygidium). Notochaetae of Terebellidae are divided in two types: distally smooth as in Pista, Eupolymnia or Lanice, or distally serrated as in Amphitritides or Paramphitrite (Fig. 5E), and each types are sub-divided in sub groups (Nogueira et al. 2010: table 4). Concerning the neurochaetae, each part of the uncinus (Fig. 1C-D) differ greatly among the genera of Terebellidae and their morphology should be examined in detail. For example, members of the genus Pista have long-handled uncini, with the handle originating from the heel (Fig. 1C), while uncini in most of the other genera have short-handles. Contrary to tendons which are soft and thin structures attached to uncini, handles are chitinous structures extended from the heel. Members of the genus Loimia are unique due to the presence of pectinate uncini, with teeth arranged 

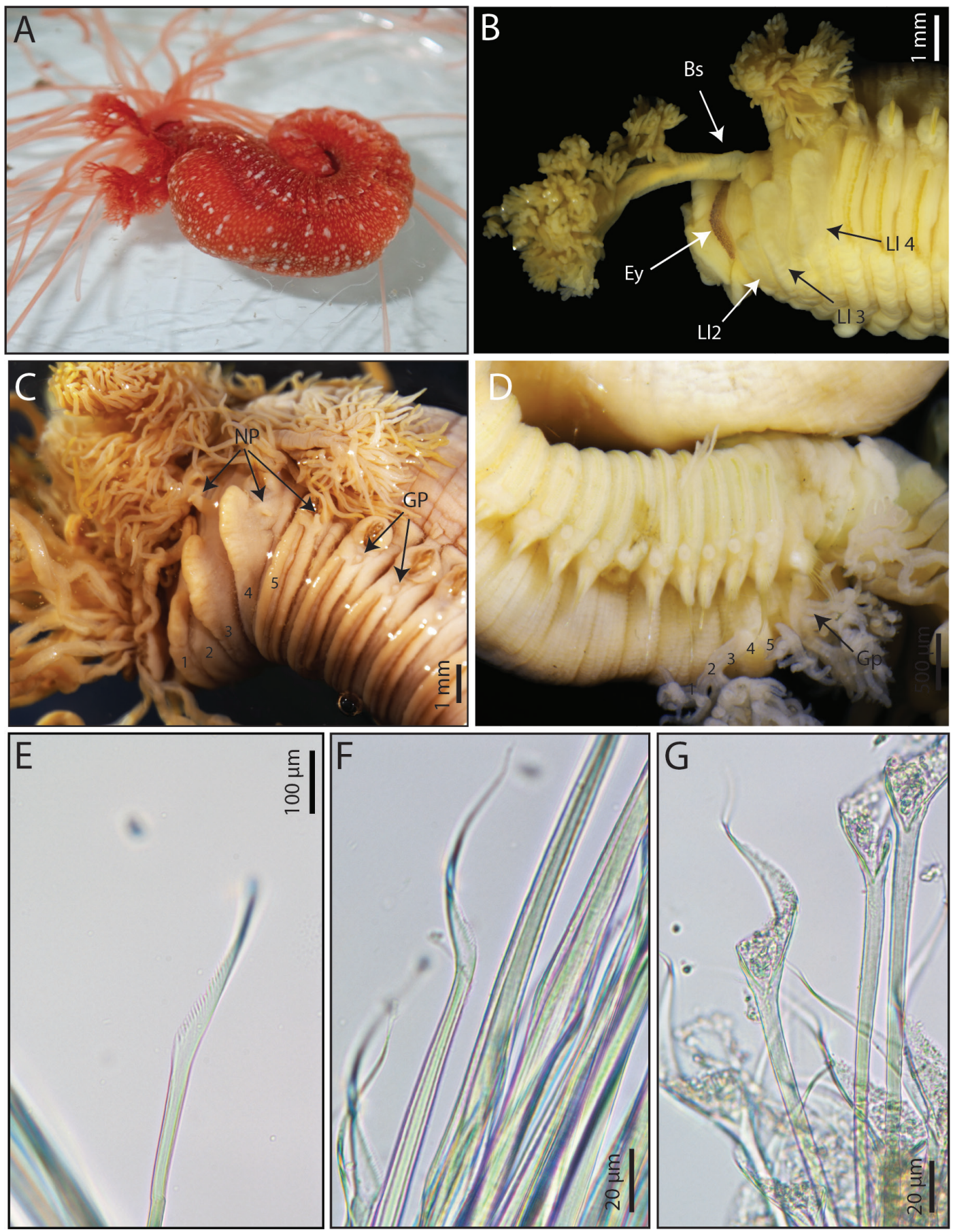

Fig. 5. Diversity of Terebellidae Johnston, 1846 (s.s.). A. Eupolymnia lacazei Lavesque, Daffe, Londoño-Mesa \& Hutchings, 2021, live specimen (paratype MNHN-IA-TYPE 2023). B. Eupolymnia gili Lavesque, Daffe, Londoño-Mesa \& Hutchings, 2021, anterior end, lateral view (holotype MNHNIA-TYPE 2020). C. Amphitrite edwardsii (Quatrefages, 1866), anterior end, lateral view (MNHN-IAPNT 126). D. Terebella banksyi Lavesque, Daffe, Londoño-Mesa \& Hutchings, 2021, anterior end, lateral view (holotype MNHN-IA-TYPE 2037). E. Paramphitrite dragovabeci Lavesque, Daffe, Londoño-Mesa \& Hutchings, 2021, notochaeta, SG XI (paratype MNHN-IA-TYPE 2030). F. Terebella cf. lapidaria Linnaeus, 1767, notochaetae, SG IX (MNHN-IA-PNT 131). G. Terebella lapidaria, notochaetae, posterior segments (MNHN-IA-PNT 131). Abbreviations: Bs = branchial stem; Ey = eyes; $\mathrm{Gp}=$ genital papillae; $\mathrm{Ll}=$ lateral lobes; $\mathrm{Np}=$ nephridial papillae. Numbers referring to segments . 

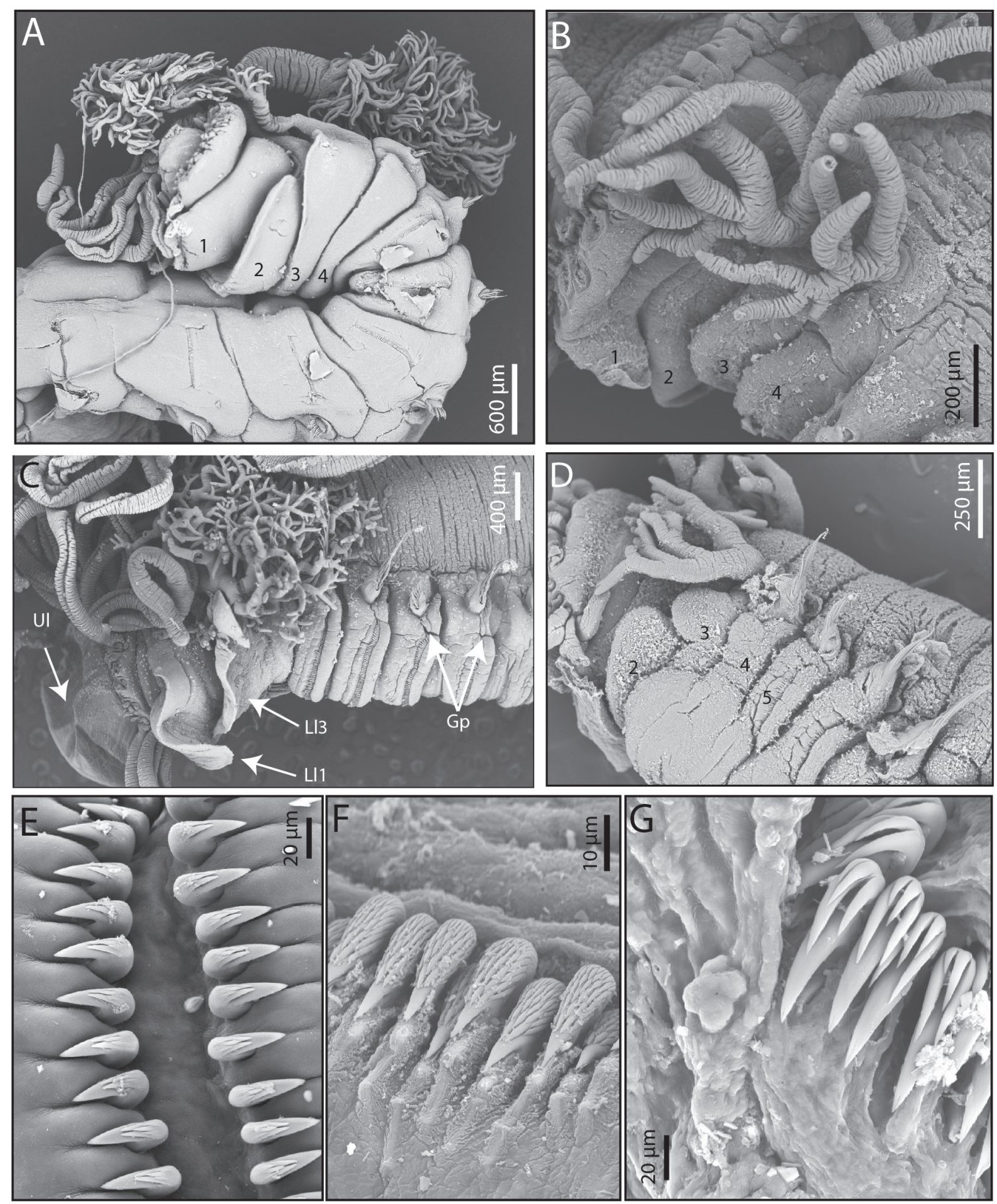

Fig. 6. Diversity of Terebellidae Johnston, 1846 (s.s.) , SEM.A. Pista sauriaui Lavesque, Daffe, LondoñoMesa \& Hutchings, 2021, anterior end, lateral view (paratype MNHN-IA-TYPE 2036). B. Paramphitrite dragovabeci Lavesque, Daffe, Londoño-Mesa \& Hutchings, 2021, anterior end, lateral view (paratype MNHN-IA-TYPE 2030). C. Lanice kellyslateri Lavesque, Daffe, Londoño-Mesa \& Hutchings, 2021, anterior end, lateral view (paratype MNHN-IA-TYPE 2028). D. Eupolymnia meissnerae Lavesque, Daffe, Londoño-Mesa \& Hutchings, 2021, anterior end, ventro-lateral view (paratype MNHN-IA-TYPE 2025). E. Lanice kellyslateri, thoracic uncini (paratype MNHN-IA-TYPE 2028). F. Paramphitrite dragovabeci, uncini SG XIV (paratype MNHN-IA-TYPE 2030). G. Eupolymnia meissnerae, uncini SG VIII (paratype MNHN-IA-TYPE 2025). Abbreviations: $\mathrm{Gp}=$ genital papillae; $\mathrm{Ll}=$ lateral lobes; $\mathrm{Ul}=$ upper lip. Numbers referring to segments. 
vertically in a single row (Fig. 1D), while other species have multiple transverse rows of secondary teeth above the main fang (Fig. 6E-G). The dorsal button is generally well developed and situated about midway between the base of the main fang and the tip of the prow, but is inconspicuous in specimens of Lanice and can be closer to the tip of the prow, as in Eupolymnia gili or the base of the main fang, as for Artacama proboscidea. Finally, the prow and the heel vary in shape and can be distally rounded or pointed.

Key to European species of Terebellidae (sensu stricto) (after Lavesque et al. 2021).

1. Peristomium ventrally forming a large conical process .......Artacama proboscidea Malmgren, 1866

- Absence of peristomial ventral process....

2. Notochaetae on more than 25 segments, body uniform throughout ............................................. 3

- Notochaetae on 25 or fewer segments, thorax and abdomen clearly defined .................................. 5

3. Branchiae absent

- Branchiae present 4 (Terebella)

4. Branchiae on SG II-IV, five pairs of nephridial and genital papillae

Terebella lapidaria Linnaeus, 1767

- Branchiae on SG II-III and V, 12 pairs of nephridial and genital papillae

Terebella banksyi Lavesque, Daffe, Londoño-Mesa \& Hutchings, 2021

5. Absence of branchiae

- Presence of branchiae

6. Uncini from $\mathrm{CH} 2$

- Uncini from $\mathrm{CH} 3$ 11 (Proclea)

- Uncini from $\mathrm{CH} 7$ Laphania boecki Malmgren, 1866

7. Notopodia with two types of notochaetae

- Notopodia with one type of notochaetae only

8. Notochaetae on 10 segments Leaena ebranchiata (Sars, 1865)

- Notochaetae on more than 13 segments 9 (Phisidia)

9. Uncini in double rows on about 24 segments, eyespots present

- Uncini in double rows on 9-10 segments, eyespots absent

Phisidia oculata (Langerhans, 1880) .Phisidia aurea Southward, 1956

10. Notochaetae on 11 segments Lanassa venusta (Malm, 1874)

- Notochaetae on 15 segments Lanassa nordenskioldi Malmgren, 1866

- Notochaetae on 16 segments Stschapovella tatjanae Levenstein, 1957

11. Ventral lobe of SG II smooth and moderately protruding Proclea graffii (Langerhans, 1884)

- Ventral lobe of SG II papillose and clearly protruding Proclea malmgreni (Ssolowiew, 1899)

12. All notochaetae subdistally denticulate

- Notochaetae smooth

13. Lateral lobes absent 14 (Amphitritides)

- Lateral lobes present 15 
14. Notochaetae on 17-20 segments; 8 segments with nephridial and genital papillae

Amphitritides gracilis (Grube, 1860)

- Notochaetae on 24 segments; 11-13 segments with nephridial and genital papillae Amphitritides kuehlmanni Arvanitidis \& Koukouras, 1995

15. Two pairs of arborescent branchiae, on SG II-III 16 (Paramphitrite)

- Three pairs of unbranched branchiae, on SG II-IV 17 (Amphitrite)

16. Branchiae separated by a wide dorsal gap, developed lateral lobes on SG II-IV, absence of nephridial papillae on SG IV

Paramphitrite dragovabeci Lavesque, Daffe, Londoño-Mesa \& Hutchings, 2021

- Branchiae without dorsal gap, small lateral lobes on SG II-IV, presence of nephridial papillae on SG IV

17. Notopodia present on 17 chaetigers

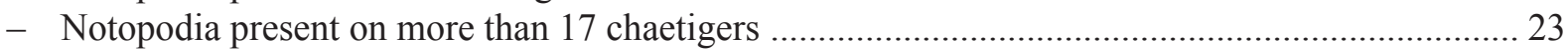

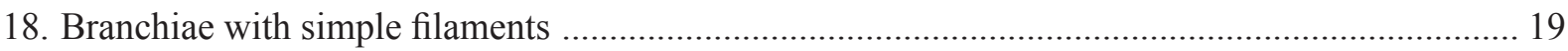

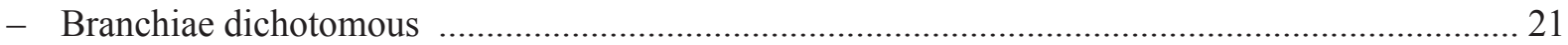

19. Seven pairs of nephridial and genital papillae (SG III and SG VI-XI)

Amphitrite cirrata Müller, 1771

- Four pairs of nephridial and genital papillae (SG III and SG VI-VIII) .......................................... 20

20. Branchiae arising from short stem or directly from body wall

Amphitrite fauveli Jirkov, Ravara \& Cunha, 2018

- Branchiae arising from large and stout stem Amphitrite rzhavskyi Jirkov, 2020

21. Nine pairs of nephridial and genital papillae, on SG III-XI

- Six pairs of nephridial and genital papillae, on SG III-VIII

Amphitrite edwardsi (Quatrefages, 1866)

22. Branchiae with few ramifications, neuropodia of first abdominal segment less than half size of neuropodia of last thoracic segment Amphitrite affinis Malmgren, 1866

- Branchiae with many ramifications, neuropodia of first abdominal segment about same size as neuropodia of last thoracic segment Amphitrite variabilis (Risso, 1826)

23. Notopodia present on 19 chaetigers Amphitrite groenlandica Malmgren, 1866

- Notopodia present on more than 19 chaetigers

24. Notopodia present on 21 chaetigers, 9-10 pairs of nephridial and genital papillae

Amphitrite grayi Malmgren, 1866

- Notopodia present on more than 21 chaetigers, more than 10 pairs of nephridial and genital papillae

25. Notopodia present on first 23-27 chaetigers, 16 pairs of nephridial and genital papillae, uncini in double rows on SGXI-XXV

Amphitrite figulus (Dalyell, 1853)

- Notopodia present on first 22-24 chaetigers, 13-15 pairs of nephridial and genital papillae, uncini in double rows almost to end of abdomen Amphitrite rubra (Risso, 1826)

26. Absence of lateral lobes 27 (Nicolea)

- Presence of lateral lobes 28 
27. Notochaetae on 15 segments, branchiae with short stems ............Nicolea zostericola (Ørsted, 1844)

- Notochaetae on 17-18 segments, branchiae with long stems ....Nicolea venustula (Montagu, 1819)

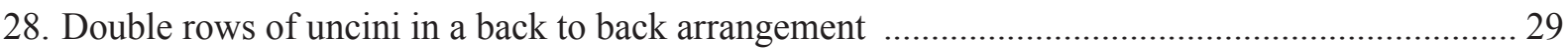

- Double rows of uncini in a face-to-face or intercalated arrangement ............................................. 32

29. Uncini pectinate, with teeth in a single vertical row

$30($ Loimia $)$

- Uncini avicular, with several transverse rows of secondary teeth

31 (Lanice)

30. Eyespots present, pygidium without distinct papillae, thoracic uncini with 4-5 rows of secondary teeth

Loimia medusa (Savigny, 1822)

- Eyespots absent, pygidium with 14 distinct papillae, thoracic uncini with 6 rows of secondary teeth

Loimia ramzega Lavesque, Bonifácio, Londoño-Mesa, Le Garrec \& Grall, 2017

31. Ventral shields fused on SGII-IV, notopodia short, neuropodia as low ridges, upper lip dorsally pigmented

Lanice conchilega (Pallas, 1766)

- Ventral shields well defined on SGIII-IV, notopodia well developed, neuropodia prominent, upper lip without pigmentation

Lanice kellyslateri Lavesque, Daffe, Londoño-Mesa \& Hutchings, 2021

32. Notopodia on 15-16 segments, a single pair of short dichotomously branchiae 33 (Axionice)

- Notopodia on 17 segments

33. Notopodia on 15 segments Axionice flexuosa (Grube, 1860)

- Notopodia on 16 segments Axionice maculata (Dalyell, 1853)

34. Short-handled avicular uncini throughout

- Long-handled avicular uncini, at least on anterior neuropodia (i.e., SGV-VII) $40($ Pista $)$

35. A single pair of plumose branchiae 36 (Pistella)

- Three pairs of branching branchiae 37 (Eupolymnia)

36. Branchial filaments arranged in distinct tiers, ventral shields on SG II-XV, dorsal crest on SG III .. Pistella rovignensis Mikac \& Hutchings, 2017

- Branchial filaments arranged in spiral, ventral shields on SG VI-XX, dorsal crests on SG II-IV .... Pistella lornensis (Pearson, 1969)

37. Branchiae with long stems

- Branchial stems short or absent

38. Abdominal neuropodia dorsally pointed, lateral lobes translucent

Eupolymnia gili Lavesque, Daffe, Londoño-Mesa \& Hutchings, 2021

- Abdominal neuropodia rounded, lateral lobes not translucent

Eupolymnia lacazei Lavesque, Daffe, Londoño-Mesa \& Hutchings, 2021

39. First pair of branchiae without stem, lateral lobes on SG III bilobed, lateral lobes of SG II small ... Eupolymnia nebulosa (Montagu, 1819)

- First pair of branchiae with short stem, lateral lobes on SG III spherical, lateral lobes of SG II welldeveloped Eupolymnia meissnerae Lavesque, Daffe, Londoño-Mesa \& Hutchings, 2021

40. A single branchia inserted mid-dorsally on SG II

- All branchiae paired

Pista labruneae Lavesque, Daffe, Londoño-Mesa \& Hutchings, 2021

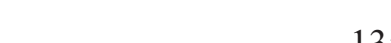


41. One or two pairs of branchiae

- Three pairs of branchiae Pista cretacea (Grube, 1860)

42. One pair of branchiae

- Two pairs of branchiae

43. Absence of lateral lobes on SG II Pista mirabilis McIntosh, 1885*

- Presence of lateral lobes on SG II

44. Lateral lobes present on SG I-III, small on SG I and III

- Lateral lobes present on SG II-III, well developed on SG III

Pista bansei Saphronova, 1988*

45. Lateral lobes well developed on SG II, asymmetrical on SG III

Pista colini Labrune, Lavesque, Bonifácio \& Hutchings, 2019

- Lateral lobes narrow on SG II, rectangular on SG III

Pista adriatica Mikac \& Hutchings, 2017

46. Uncini of SG V very high, with a vertical prow Pista mediterranea Gaillande, 1970

- Uncini of SG V with regular size

47. Absence of long-handled uncini on SG X (CH5)

- Presence of long-handled uncini on SG X

48. Lateral lobes on SGI short, on SGIV long

Pista cristata (Müller, 1776)

- Lateral lobes on SGI large, on SGIV very small

Pista sauriaui Lavesque, Daffe, Londoño-Mesa \& Hutchings, 2021

49. Lateral lobes on SG I small, on SG IV well developed, eyespots absent

Pista wui Saphronova, 1988*

- Lateral lobes on SG I absent, on SG IV small, almost inconspicuous, eyespots present

Pista miosseci Lavesque, Daffe, Londoño-Mesa \& Hutchings, 2021

* doubtful record, probably a misidentification.

Family Trichobranchidae Malmgren, 1866

Figs $1 \mathrm{~A}, 7-8$

Diagnosis (after Hutchings et al. 2021a, most important diagnostic characters highlighted in bold)

Transverse prostomium attached to dorsal surface of upper lip; basal part as thick crest, eyespots sometimes present; distal part at base of upper lip or extending along lip. Buccal tentacles of two types, uniformly cylindrical and expanded at tips, spatulate. Peristomium forming lips, sometimes also a ventral lobe, as an extension of the lower lip; lips expanded, circular upper lip, distal margin folded or convoluted; lower lip button-like, usually continuing by ventral lobe, or expanded, forming large scoop-shaped process (Figs 7A-C, 8A, C-D). Segment I usually short, frequently only visible ventrally; anterior margin of anterior segments with lobes as low, even-length collars covering posterior margins of preceding segments, at least ventrally; ventro-lateral or lateral lobes on anterior segments sometimes present. Anterior segments poorly glandular ventrally, smooth, discrete shields absent; midventral groove extending from posterior segments with notopodia. Two to four pairs of branchiae, beginning from SGII, each pair with single, thick and elongate, tapered or foliaceous filament, or two pairs fused in single four lobed structure originating mid-dorsally between SGII-III or II-IV (Figs 7C, 
8C-D). Notopodia beginning from SGIII-VI, typically terminating at SGXX; short, conical notopodia, chaetae emerging from central core on top, distal lobes absent; narrowly-winged notochaetae in both rows throughout. Neuropodia beginning on same segment as notopodia or slightly posteriorly, rarely beginning before notopodia; sessile neuropodia until termination of notopodia, neurochaetae emerging directly from body wall, as rectangular to foliaceous pinnules after termination of notopodia; thoracic neurochaetae as acicular uncini (Figs 1A, 7D, 8F), sometimes with small hood or beard below main fang; avicular abdominal uncini, with secondary teeth in rows on top and laterally to main fang. Nephridial papillae on SGIII usually present, other papillae sometimes present on SGVI and SGVII, but reduced to inconspicuous in most taxa. Pygidium smooth to slightly crenulate, sometimes bilobed.

\section{Remarks}

In the past, the Trichobranchidae family was considered to be a subfamily of Terebellidae (Fauvel 1927; Day 1967; Garrafoni \& Lana 2004), but recent phylogenetic analyses support the hypothesis of a valid family (Glasby et al. 2004; Nogueira et al. 2013). The family includes only three genera, i.e., Octobranchus Marion \& Bobretzky, 1875, Terebellides Sars, 1835, and Trichobranchus Malmgren, 1866. For Trichobranchus and Octobranchus, only three species of each occur in Europe. The genus Terebellides is very speciose and is represented in Europe by 19 species, 13 of them described in the last two years (Lavesque et al. 2019b; Parapar et al. 2020a) (Table 1).

\section{Main morphological characters for European species}

The number of branchiae is the best character to discriminate the different genera, with Terebellides having a single large branchia, Trichobranchus with two or three pairs of branchiae and finally Octobranchus with four pairs.

Trichobranchus species are easy to differentiate based on the number of branchiae (two vs three) (Figs 7C, 8C) and the absence or presence of eyespots. In Octobranchus, the species differ by the shape of the branchiae (Fig. 8D) and the number of secondary teeth above the main fang of the uncini. Regarding Terebellides species, recent studies highlighted that several characters are very important for identification to the species level (Lavesque et al. 2019a; Parapar et al. 2020a, 2020b). However, as many cryptic species occur at a small geographical scale (Nygren et al. 2018), which currently are confirmed only by molecular analyses (Parapar et al. 2020a) much more work needs to be done to resolve all the species present.

BRANCHIAE. Even if Terebellides branchiae seem to be very similar within the genus (Figs 7A-B, 8A-B), several morphological characters permit the discrimination of species, such as the presence of a fifth anterior branchial lobe (e.g., T. europaea), the degree of fusion of both upper and lower lobes (e.g.. not fused on T. ceneresi), the presence of long terminal filaments (e.g., in T. shetlandica) or short posterior processes (Fig. 7B), and finally the presence and the shape of papillae situated on the margins of the branchial lamellae (Fig. 8B) (e.g., T. lilasae).

NotochAETAE FROM FIRST CHAETIGER. The size of notochaetae of the first chaetiger varies between species. For most of the species, these chaetae are of a similar size compared to those of the following chaetigers. However, they can be absent or much shorter (e.g., T. ceneresi) or much longer (e.g., T. mediterranea).

Presence of geniculate chaetae on one or two chaetigers. The geniculate chaetae are exclusive to members of Terebellides and they are typically present on CH6 (SG VIII) only (Fig. 8E), but in some species they are present on two chaetigers, as for example in T. bigeniculatus.

UnCINI DENTICULATION. The different types of uncini follow the classifications provided by Parapar et al. (2020b) for thoracic uncini (Fig. 8F) and Parapar et al. (2020a) for abdominal uncini. These 
classifications are based on the ratio between the length of the main fang (rostrum) and the crest of secondary teeth (capitium), and the size and number of the secondary teeth.

Thoracic Ciliated papillae. Following the recent study of Parapar et al. (2020a), the absence or the presence of thoracic ciliated papillae allow for the discrimination of Terebellides species. These papillae are situated dorsally to the thoracic notopodia (see for example Parapar et al. 2020a; Fig. 7B).

METHYL GREEN PATTERN. The colouration of Terebellides specimens prior to identification is essential. Indeed, MG staining highlights the presence and the shape of the glandular region of the third thoracic chaetiger (e.g., undulating glandular region present and in members of $T$. gentili, oval for T. lilasae
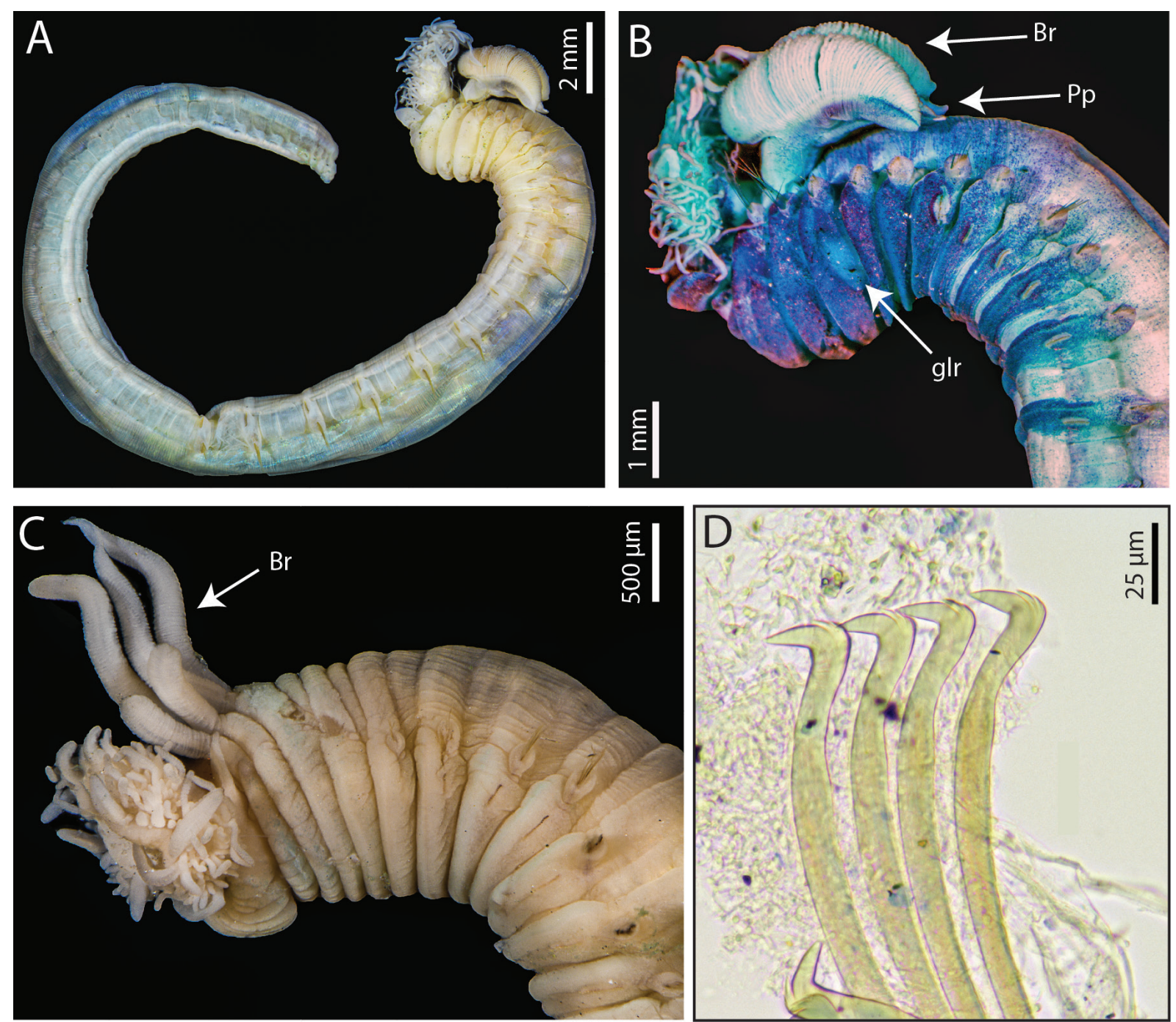

Fig. 7. Diversity of Trichobranchidae. A. Terebellides lilasae Lavesque, Hutchings, Daffe, Nygren \& Londoño-Mesa, 2019, entire specimen, lateral view (MNHN-IA-TYPE 1879). B. Terebellides lilasae, anterior end, lateral view, methyl green staining (MNHN-IA-TYPE 1879). C. Trichobranchus glacialis Malmgren, 1866, anterior end, lateral view (MNHN-IA-PNT 96). D. Terebellides sp., thoracic acicular uncini (SMA-BR-Terebellides-KER1). Abbreviations: $\mathrm{Br}=$ Branchiae; $\mathrm{glr}=$ glandular region; $\mathrm{Pp}=$ Posterior process. 

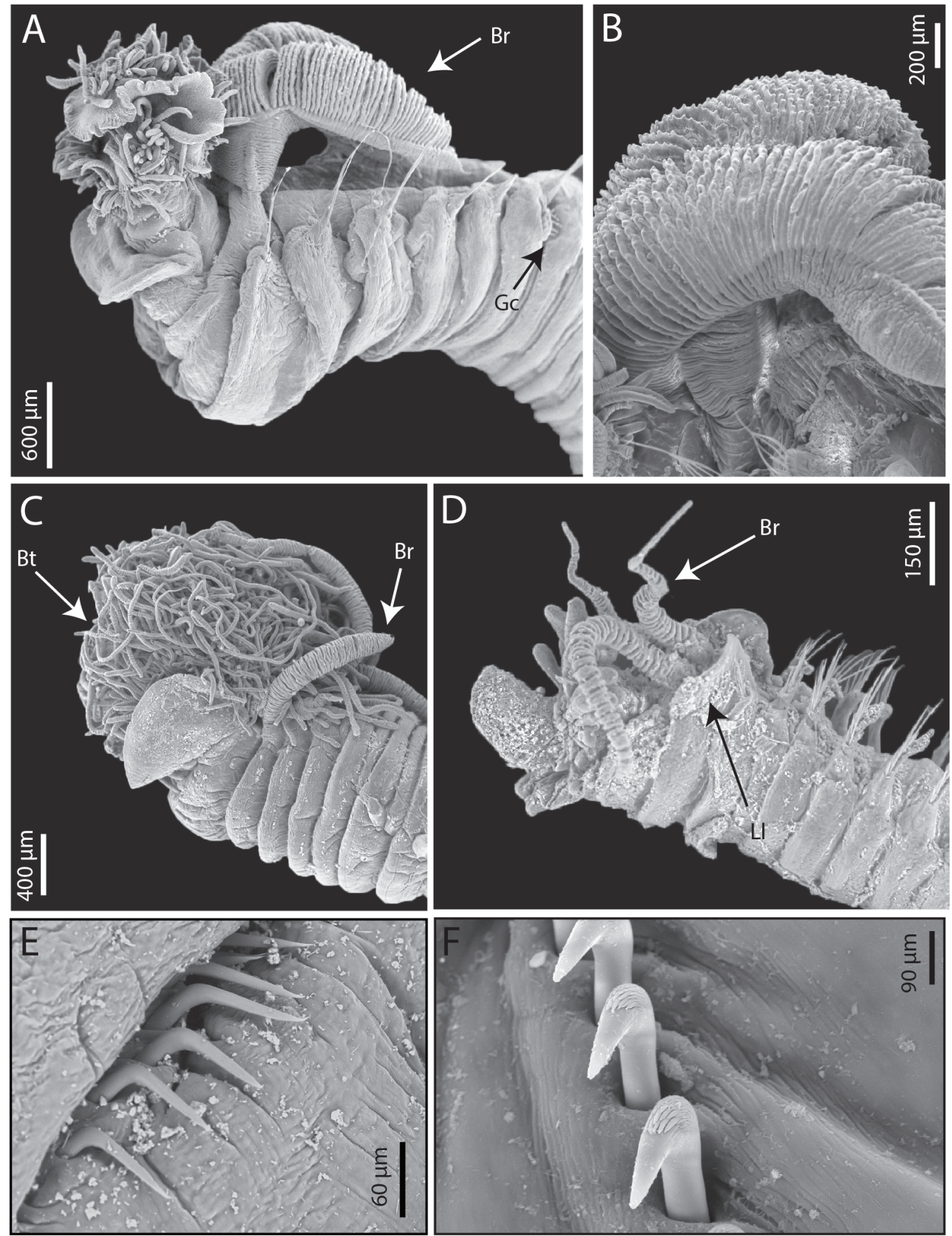

Fig. 8. Diversity of Trichobranchidae, SEM. A. Terebellides gentili Lavesque, Hutchings, Daffe, Nygren \& Londoño-Mesa, 2019, anterior end, lateral view (MNHN-IA-TYPE 1873). B. Terebellides lilasae Lavesque, Hutchings, Daffe, Nygren \& Londoño-Mesa, 2019, branchia, lateral view (MNHNIA-TYPE 1881). C. Trichobranchus glacialis Malmgren, 1866, anterior end, lateral view (SMA-BRTricho-05). D. Octobranchus lingulatus (Grube, 1863), anterior end, lateral view (MNHN-IA-PNT 94). E. Terebellides resomari Lavesque, Hutchings, Daffe, Nygren \& Londoño-Mesa, 2019, geniculate chaetae (paratype MNHN-IA-TYPE 1892). F. Terebellides lilasae, thoracic uncini (SMA-ARCTerebellides-VOG8-1). Abbreviations: $\mathrm{Br}=$ Branchiae; $\mathrm{Bt}=$ Buccal tentacles; $\mathrm{Gc}=$ Geniculate chaetae; $\mathrm{Ll}=$ Lateral lobes. 
Fig. 7B) and the compact/striped pattern of the ventral part of anterior chaetigers (e.g., CH4 (SG VI) white in T. ceneresi).

Key to European species of Trichobranchidae (after Lavesque et al. 2019a and Parapar et al. 2020a)

1. One large branchia consisting of a stem and four lobes with transverse lamellae .....5 (Terebellides)

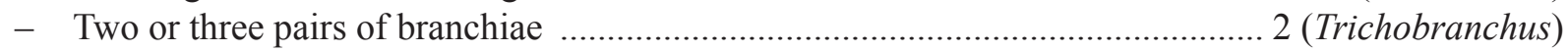

- Four pairs of branchiae ........................................................................................ 4 (Octobranchus)

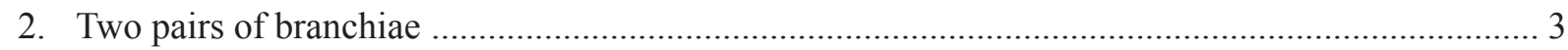

- Three pairs of branchiae, eyespots present ……...................................................................... Trichobranchus glacialis Malmgren, 1866

3. Eyespots absent

Trichobranchus roseus Malm, 1874

- Eyespots present

... Trichobranchus demontaudouini Lavesque, Hutchings, Daffe, Nygren \& Londoño-Mesa, 2019

4. Pairs of branchiae of different shapes; abdominal uncini with three rows of secondary teeth above the main fang Octobranchus floriceps Kingston \& Mackie, 1980

- All pairs of branchiae similar; abdominal uncini with two rows of secondary teeth above the main fang Octobranchus lingulatus (Grube, 1863)

- Bases of branchiae covered by dorso-lateral lobes, abdominal uncini with two rows of secondary teeth above the main fang Octobranchus sikorskii (Leontovich \& Jirkov. 2001)

5. Geniculate acicular chaetae on CH5 (SG VII) and CH6 (SG VIII)

Terebellides bigeniculatus Parapar, Moreira \& Helgason, 2011

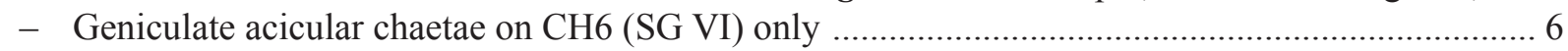

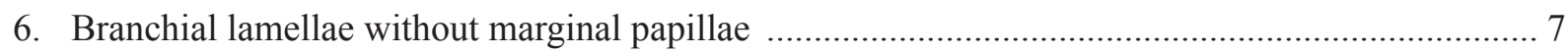

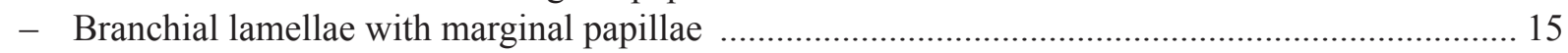

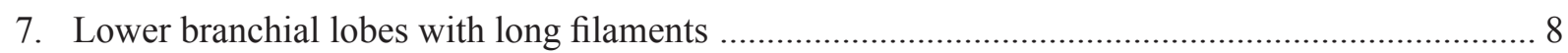

- Lower branchial lobes with or without short projections ........................................................... 9

8. Glandular region on $\mathrm{CH} 3$ (SG V) present; branchial lamellae pointed; notochaetae from $\mathrm{CH} 1$ longer than following ones; dorsal papillae absent

Terebellides parapari Lavesque, Hutchings, Daffe, Nygren \& Londoño-Mesa, 2019

- Glandular region on CH3 (SG V) absent; branchial lamellae rounded; all notochaetae equal-sized; dorsal papillae present

Terebellides shetlandica Parapar, Moreira \& O’Reilly, 2016

9. Ventral white band present on CH4 (SG VI) after MG staining ................................................ 10

- No distinct pattern on CH4 (SG VI) after MG staining ................................................................11

10. Large species ( $>30 \mathrm{~mm}$ ); $5^{\text {th }}$ branchial lobe present; notochaetae of CH1 (SG III) similar to following ones; main fang of thoracic uncini straight Terebellides gracilis Malm, 1874

- Small species $(<20 \mathrm{~mm}) ; 5^{\text {th }}$ branchial lobe absent; notochaetae of CH1 (SG III) absent or shorter than following ones; main fang of thoracic uncini 'eagle head' (= curved) shaped

Terebellides ceneresi Lavesque, Hutchings, Daffe, Nygren \& Londoño-Mesa, 2019

11. First notopodia and notochaetae longer than following ones

Terebellides mediterranea Parapar, Mikac \& Fiege, 2013

- First notopodia and notochaetae similar or shorter than following ones 
12. Large-sized species $(>50 \mathrm{~mm})$; dorsal rounded projections on $\mathrm{CH} 1-\mathrm{CH} 5$ conspicuous ............... 13

- Small-sized species $(<20 \mathrm{~mm})$; dorsal rounded projections on CH1-CH5 absent; main fang of thoracic uncini straight

13. Abdominal uncini of type 1 (length of capitium about 0.7 length of the main fang, capitium simple consisting of a few, wide denticles)

Terebellides kongsrudi Parapar, Capa, Nygren \& Moreira, 2020 and

Terebellides bakkeni Parapar, Capa, Nygren \& Moreira, 2020 complex

- Abdominal uncini of type 2 (capitium of about same length as main fang, capitium complex composed of a first row of 4(5) denticles and a variable number of teeth in two more rows)

Terebellides stroemii Sars, 1835

14. Glandular region on $\mathrm{CH} 3(\mathrm{SG} \mathrm{V})$ and $5^{\text {th }}$ branchial lobe both absent

Terebellides atlantis Williams, 1984

- Glandular region on CH3 (SG V) and $5^{\text {th }}$ branchial lobe both present

Terebellides gralli Lavesque, Hutchings, Daffe, Nygren \& Londoño-Mesa, 2019

15. Glandular region on $\mathrm{CH} 3$ (SG V) rounded or oval

- Glandular region on CH3 (SG V) otherwise

16. Glandular region on $\mathrm{CH} 3$ (SG V) staining in white, branchial lamellae with rounded papillae, $\mathrm{CH} 1-$ 3 without conspicuous dorsal projection

Terebellides lilasae Lavesque, Hutchings, Daffe, Nygren \& Londoño-Mesa, 2019

- Glandular region on CH3 (SG V) staining in blue, branchial lamellae with conical papillae, CH1-3 with conspicuous dorsal projection

Terebellides bonifi Lavesque, Hutchings, Daffe, Nygren \& Londoño-Mesa, 2019

17. Most branchial lamellae with marginal papillae

- Only anterior branchial lamellae with marginal papillae

18. Branchial lamellae with digitiform papillae, upper lip elongated; MG staining pattern as compact bands from $\mathrm{CH} 1-5$

Terebellides resomari Lavesque, Hutchings, Daffe, Nygren \& Londoño-Mesa, 2019

- Branchial lamellae with widely spaced, small and elongated digitiform papillae; MG staining pattern leaving white stripes from $\mathrm{CH} 1-5$

Terebellides gentili Lavesque, Hutchings, Daffe, Nygren \& Londoño-Mesa, 2019

19. Thoracic uncini type 1 (main fang vs capitium length ratio 2(3)/1; capitium with 2(3) large teeth, following ones much smaller)

Terebellides ronningae Parapar, Capa, Nygren \& Moreira, 2020

- Thoracic uncini type 3 (main fang vs. capitium length ratio 1/1; capitium with 4(5) mid-sized teeth, following ones slightly smaller)

20. Deep-water species, mostly found below $200 \mathrm{~m}$ deep

Terebellides norvegica Parapar, Capa, Nygren \& Moreira, 2020

- Shallow-water species, mostly found above $100 \mathrm{~m}$ deep

Terebellides europaea Lavesque, Hutchings, Daffe, Nygren \& Londoño-Mesa, 2019 and Terebellides scotica Parapar, Capa, Nygren \& Moreira, 2020 complex 


\section{Discussion}

\section{Why have so many new species been discovered in such well-known waters?}

In Europe (Greenland included), 109 valid species had been described since the first description of Lanice conchilega by Pallas (1766). Most of these species (i.e., 44) were described by early European taxonomists in the $18^{\text {th }}$ and $19^{\text {th }}$ centuries, and only a few during the $20^{\text {th }}$ century (12 species). However, only five species were described before the start of this project from French waters: Amphitrite edwardsii, Pista mediterranea, Polycirrus arenivorus, Polycirrus denticulatus and Thelepus setosus. In addition, four species described from French waters are now considered as nomen dubium: Lanassa proecox (SaintJoseph, 1899) which could be a postlarval stage of a known species (Fauvel 1927; Gil 2011), Polycirrus haematodes (Claparède, 1864) and Polycirrus pallidus (Claparède, 1864) for which no type material exists and the original descriptions are very brief (Glasby \& Hutchings 2014), and finally Amphitrite ramosa Risso, 1826, stated to be indeterminable based on the original description (Jirkov 2020). Since the start of the "Spaghetti Project" in 2018, more than 400 specimens were carefully examined and more than 100 molecular sequences obtained. In French coastal waters, 58 species occur, 31 of them described as new during this project. The first question we can ask ourselves is: why? Why have so many new species been discovered in such well-known waters?

How can we explain the quasi-absence of discovery of new species in France for over a century? The first reason is the difficulty to identify known European terebellids. Indeed, as commented on by Hutchings \& Lavesque (2020), the lack of literature and type material are especially challenging for taxonomists. Most of the European species were described by earlier workers who failed to designate type specimens and to deposit them in an official collection, or when they did, material is often damaged and unusable (Lavesque et al. 2021). Moreover, they provided only approximate type localities and few details on habitat preferences. Thus, comparison between new material and type material is difficult. Referring to original descriptions is not helpful either; they are usually very brief with inadequate figures, and could correspond to several species because of the lack taxonomic details (Hutchings et al. 2021a, 2021b).

The second reason, without any mystical connotation, is linked to the spectre of the priest Pierre Fauvel. Actually, the main reference work in polychaete taxonomic literature is, without any doubt, his "Faune de France" (Fauvel 1923, 1927). These two books are widely used by taxonomists, ecologists, students and private companies in France but also worldwide (Hutchings \& Kupriyanova 2018; Hutchings \& Lavesque 2020; Capa \& Hutchings 2021). Fauvel was one of the most prolific authors in the history of polychaete taxonomy with 141 accepted species described, ranking $16^{\text {th }}$ polychaetologist in the world (Pamungkas et al. 2019). Surprisingly, he described only four species from French coastal waters as most of his works were focused on the fauna from India (e.g., Fauvel 1932) or Africa (e.g., Fauvel 1918). He also described many deep sea species which are stored in the Musée Océanographique de Monaco and were sampled in the European Atlantic Ocean during the "Hirondelle" (1885-1888) and the "Princesse-Alice" (1894-1897) cruises by the Prince Albert 1t (e.g., Fauvel 1913). The specimens examined by Fauvel for his "Faune de France" were collected mainly at low tides or during dredging campaigns, while only some were received from a few colleagues (Fauvel 1923). In comparison, we had the opportunity to examine specimens from a greater variety of habitats, thanks to our RESOMAR colleagues working in eight coastal laboratories along the French coasts. With their help, we were able to compare material from a wide range of habitats, depths, and ecosystems. For example, 12 species were described from maerl (rhodolith) beds in Brittany (Lavesque et al. 2019a, 2020a, 2020b, 2021), confirming that this habitat is an important hotspot of biodiversity (Grall \& Hall-Spencer 2003; Barbera et al. 2003). Moreover, our colleagues also undertook new sampling excursions to obtain fresh material so that we could undertake molecular analyses. These analyses, coupled with morphological observations, permitted us to confirm the existence of many cryptic species belonging to several species complexes such as the "Terebellides stroemii complex", "Pista cristata complex" or "Eupolymnia nebulosa complex" 
(Lavesque et al. 2019a, 2021). Even if, as taxonomists, we work in a similar way to Grube, Malmgren, McIntosh and other early scientists spending hours behind a stereo microscope, we are fortunate to have access to advanced technologies like high resolution cameras, scanning electron microscopes, molecular laboratories and internet facilities. These technologies help us to find differences or characters that early taxonomists would have missed and easy access to all the available literature.

The third reason is the lack of accurate literature for European waters, which is intimately linked to Fauvel's work. His two volumes of the "Faune de France" were of an excellent standard for his time. But publication was time consuming and costly, and resources were lacking to update his work in subsequent decades. For a long time, to 'correctly' identify a terebellid worm from French waters meant using either Fauvel's or Holthe's books. The latter, more recent work (Holthe 1986) is based on accurate observations (type material when possible), but the diagnoses are very short and do not take into account recent valuable taxonomic characters. Moreover, this work was focused on Scandinavian waters, from Greenland to Great Britain, a large region which differs from French waters and other countries from southern Europe especially with regard to water temperatures. Fauvel's books were widely used for nearly a century in France, in Europe and also in the rest of the world. This wide use was not a major issue for decades as scientists, polychaete taxonomists in particular, were convinced by the cosmopolitanism of marine worms (Hutchings \& Kupriyanova 2018). Kristian Fauchald was the first one to suggest that polychaetes can show interesting biogeographical patterns when properly identified (Fauchald 1984). Recent studies clearly confirmed that species of polychaetes have restricted distributions and this is particularly true for terebellids. Focusing on the genus Terebellides in Northern European waters, Nygren et al. (2018) identified more than 25 species hidden within the so-called "cosmopolitan" species Terebellides stroemii. Most of these species occur only in a restricted area and specific habitat, and two species from Northern Europe are confirmed for French waters: T. europaea and T. scotica (Lavesque et al. 2019a; Parapar et al. 2020a).

The final explanation comes from the lack of taxonomic positions in France. This country is known for its famous early taxonomists such as Audouin, Gravier, Quatrefages, Saint-Joseph and Savigny, followed by few more recent ones like Bellan, Bhaud, Gillet, Laubier or Rullier. However, as many parts of the world, the number of taxonomists has dramatically declined in recent years, because taxonomy was not 'sexy' or technology-focused enough to attract policy makers attention. As a result, French scientists were almost absent from the international worm community for the last few decades. Indeed, prior to 2016, almost no French taxonomists participated in the different International Polychaete Conferences, with the exception of the conference organized in Angers in 1992. The absence of French representatives on the council of the International Polychaetology Association meetings was also a reality for several years. Fortunately, French marine biologists are now included in the RESOMAR network, allowing for a new dynamic and the recruitment of several technicians and researchers specialised in identification of benthic fauna. The lack of experienced taxonomists acting as mentors in France was compensated by the motivation of these young scientists. During the past decade, they have published numerous papers on French polychaete taxonomy (e.g., Bonifácio et al. 2015; Jourde et al. 2015; Lavesque et al. 2015, 2020c; Blake \& Lavesque 2017; Le Garrec et al. 2017) with the fundamental help of international experts such as Barnich, Blake, Glasby, Hutchings, Meißner, Londoño-Mesa and Parapar among others.

\section{What are the consequences of this hidden biodiversity?}

So what difference does it make to know that not only one, but two extremely similar species of Lanice exist? Does this hidden diversity really matter? Of course the answer is yes! Of course, it is essential to use the appropriate name when identifying a species (Lavesque et al. 2019b; Hutchings \& Lavesque 2020; Hutchings 2021). Specimens belonging to cryptic or pseudo-cryptic species are very similar and thus difficult for people, even for taxonomists, to distinguish. However, as most of these species evolve differently from a common ancestor, their life-traits and their ecological function may be different, or in 
the process of becoming different. Indeed, in his review on cryptic polychaete diversity, Nygren (2014) shows that many cryptic species can be distinguished by a number of biological characteristics, such as reproductive biology, life history, feeding biology, salinity, habitat and depth preferences or anoxia and temperature tolerances. Each species has a unique set of micro-habitat requirements and functions with important ecological consequences. Misidentification or an underestimation of the diversity thus have a strong impact on ecological studies.

The sand mason worm, Lanice conchilega, is a perfect example to illustrate this point. By aggregating sand particles on its tube, this species acts as ecosystem engineer for forming reef-like structures (Rabaut et al. 2009; Hutchings et al. 2021b). The presence of these biogenic structures increases habitat quality and enhances local biodiversity by changing hydrodynamics and nature of the shore, increasing habitat stability and oxygen supply, and finally creating heterogeneity in a uniform environment (Van Hoey et al. 2008). This habitat is thus very attractive for predators like fishes and foraging waders, and thanks to its high functional value, this habitat also has high conservation value (Godet et al. 2008). By contrast, in Arcachon Bay, the very similar species L. kellyslateri has a scattered distribution with worms appearing solitary. Maybe this absence of a "reef structure" could be linked to a specificity of this new species or to the particular environment occurring in this lagoon. These worms from Arcachon Bay may not be attractive for birds and perhaps policy makers would be unlikely to protect this species and its habitat. As we can see, the stakes can be high when considering cryptic species individually.

Another example worth considering is the strawberry worm Eupolymnia nebulosa. Experiments conducted on specimens sampled in the Gulf of Lion (Mediterranean Sea) allowed for insights into its feeding mode and tube building (Grémare 1988; Grémare et al. 1989; Grémare \& Amouroux 1990), its bioturbation activity (Maire et al. 2007) and development (Bhaud 1988; Bhaud \& Grémare 1988). Another study by Grémare (1986) highlighted that two populations, one from Banyuls-sur-Mer (Gulf of Lion), the second from Dinard (English Channel) had different reproductive modes. However, Lavesque et al. (2021) have shown that specimens sampled from Banyuls-sur-Mer belonged to two new species: E. lacazei and Eupolymnia sp. C. Additionally, specimens from Normandy and Brittany (English Channel) belonged to a third new species: E. gili. All these specimens were previously identified as E. nebulosa, but clearly belong to three cryptic species. We can therefore observe that these differences in reproductive modes can be linked to different species rather than different populations, as previously suggested by Martin et al. (1996). Discovery of multiple species with restricted distributions has implications for conservation. For example, it may be assumed that isolated populations can easily recover from local disasters (oil spill for example) by recruitment from nearby populations. But if it turns out that a species previously thought to be widespread is really several different species, this may have implications for recovery from local perturbations.

Regarding non-indigeneous species (NIS), misidentifications can have a significant impact on the understanding of ecosystems, and cascading consequences for environmental management if they are detected too late. Frequently, exotic species are often morphologically very similar to native species. As they are not reported from European waters, they are absent from identification keys restricted to the local area. It is therefore essential that the most up-to-date and relevant literature is used to identify species for ecological monitoring studies. Even if this is time consuming and expensive, the species which are typically found in an ecosystem should be regularly checked in detail by using a complete diagnosis, and not just by means of outdated keys that will of course give a poor result. Particular attention should be paid to sensitive areas, where NIS are known to occur, such as harbours, marinas and oyster farms. For example to illustrate this problem, using the blood-worm Marphysa sanguinea (Montagu, 1813) which was largely reported from Arcachon Bay for decades. However, after a thorough morphological and molecular analysis, a second species, new for science was found, i.e., Marphysa victori Lavesque, Daffe, Bonifácio \& Hutchings, 2017. This discovery may seem anecdotal, but after extensive investigations, 
we could confirm that this species native to South East Asia was probably introduced into the bay via oyster transfers in the 1970's, after mass mortalities of Portuguese oysters (Lavesque et al. 2020c). Moreover, $M$. victori is an important economic resource as bait and collected both by recreational and professional fishermen, with about 1 million worms traded per year (Lavesque et al. 2017b), most of them shipped live and sold in Western Mediterranean fishing shops in France (Lavesque et al. 2020c). Similarly, the presence of the Asiatic terebellid Thelepus japonicus was recently reported for the first time in Europe. Again, its presence in Arcachon Bay and in Normandy is linked to oyster farming with a probable introduction from Japan to Arcachon Bay via oyster transfers and a secondary introduction from Arcachon to Normandy by local transfers (Lavesque et al. 2020a). Prior to the "Spaghetti Project", this species was confused with Thelepus setosus, originally described from France, and therefore absent from European identification keys.

Finally, knowing the exact number of species within a region, or at least the number as close to reality as possible, is fundamental to understanding biodiversity issues. In the context of the extent of the biodiversity crisis, ignoring cryptic species leads to an underestimation of the species richness in the oceans (Bickford et al. 2007; Nygren 2014). Describing this cryptic diversity is absolutely fundamental in the context of the biodiversity crisis (Bickford et al. 2007). We cannot assess the loss of biodiversity in an anthropogenic context if we do not know how many species really occupy an area. Similarly, we cannot identify areas of endemism or areas of biological interest, without knowledge of cryptic species. If we just take into account the results of this "Spaghetti Project", the biodiversity of terebellids has exploded recently, with 31 new species for French waters. Of course, we know that all these new species are not really new but have just been overlooked for ages, representing a hidden biodiversity. The alarming message of how much biodiversity has been underestimated must be clearly conveyed to the public, the politicians and the managers. In the same way, we need to know exactly which species live in an ecosystem to evaluate the effects of global change. For example, recent studies tend to prove a "tropicalization" of the Bay of Biscay, with several species belonging to different biological groups (algae, fishes, decapods, molluscs or worms) shifting their northern distribution limit from tropical regions north to the southern part of the Bay of Biscay (Portugal, Spain and South of France) (Lima et al. 2007; Arias \& Crocetta 2016; Encarnação et al. 2019; Schäfer et al. 2019). Among these species, at least one of them could become problematic. Indeed, the bearded fireworm Hermodice carunculata (Pallas, 1766), originated from the West Indies and recently observed in southwestern Iberian Peninsula (Encarnação et al. 2019), can cause severe pain if its stinging chaetae come into contact with human skin.

\section{What remains to be done with these Spaghetti worms?}

We, as taxonomists, have the responsibility to share our studies and make sure that our work reaches a wide audience. Scientific papers and international conferences are not sufficient and we should use a variety of media (TV, newspapers, social media and blogs) to communicate our findings (Hutchings 2020). Biodiversity is not restricted to geeks of taxonomy and our mission is to help students, ecologists and other professionals to put the right name on the right animal (Hutchings \& Lavesque 2020). We also have to explain to politicians why taxonomy is important to the economy and biodiversity conservation, especially with regards to zoning plans for marine parks or management of marine pests (Hutchings $2020,2021)$. We have to produce easy to use identification keys, which allows people to differentiate species from cryptic complexes if possible. Our keys should be web-based and thus widely available to the wider biological community (Hutchings et al. 2021b). We, as experts, should be available to help people to identify or confirm their identifications, especially if those seeking for help come from countries lacking taxonomists and/or accurate literature.

Even if our "Spaghetti Project" permitted the improvement of the knowledge of terebellids from French waters, there is still a lot to be done. Firstly, most of the specimens examined were collected in French 
coastal waters, with the exception of some worms sampled from the deep Capbreton canyon (Lavesque et al. 2019a). The exploration of off-shore deep sea areas should be enhanced in order to have a better understanding of the distribution of these species. Some regions, like the eastern part of the French Mediterranean Sea, were poorly surveyed due to absence of benthic ecologists and samples (i.e., Marseille and Villefranche-sur-mer). This project has highlighted the presence of at least another eight undescribed species in France, based on molecular results. These "orphan" sequences belonged to small or damaged specimens, which were not in good enough condition to be described morphologically. Nygren et al. (2018) obtained similar results while working on Terebellides from Northern Europe; they obtained sequences belonging to 14 still undescribed species (Parapar et al. 2020a). Many more new species probably occur in other parts of Europe where this group was not really studied in detail before, for example in the UK or Italy to name but a few. As discussed before, due to species having restricted distributions (Nygren et al. 2018), more local studies are needed to give us a better picture of the true biodiversity of the region. Globally, some regions like Australia and Brazil are relatively well studied, leading to descriptions of tens of species (Hutchings et al. 2021b), but several regions in the world represent a "taxonomic desert" for terebellids like African, Indian and polar regions (Hutchings et al. 2021b; Capa \& Hutchings 2021). So this "Spaghetti Project" could provide a blue print for what is needed in other parts of the world.

For the stability of taxonomic nomenclature, it is important to erect neotypes for old European species described by early naturalists. Indeed, most of these species were only subsequently designated as type species of genera, and very often type specimens were not designated or do not exist anymore and original descriptions are very brief according to current standards. During this project, we highlighted this need for several species like Trichobranchus glacialis and Octobranchus lingulatus, both type species of their genera (Lavesque et al. 2019a), Polycirrus denticulatus (Lavesque et al. 2020b), Amphitrite edwardsii and A. figulus, Eupolymnia nebulosa and E. nesidenis (the type species of the genus), Lanice conchilega (the type species of the genus), and finally Pista cristata (the type species of the genus) which is currently being redescribed (Londoño-Mesa et al. in prep.; Lavesque et al. 2021) (Fig. 9; Table 1). Obtaining molecular sequences from neotypes is also crucial for future comparison and integrative taxonomy. This ensures that every species will have a modern description based on morphological and molecular tools. Undoubtedly, fixing neotypes will allow taxonomists to describe new species, as they will have a reference point for comparison. When Parapar \& Hutchings (2014) designated a neotype for T. stroemii, they opened the door to the description of 13 new species of Terebellides from Europe, with most of these new species identified in the past as T. stroemii (Lavesque et al. 2019a; Parapar et al. 2020a).

To conclude, the collaborative "Spaghetti Project", supported by numerous enthusiastic people was a real success story. We are aware that some areas and habitats along the French coast are underrepresented in this study but nonetheless, we are sure that it will facilitate the discovery of additional undescribed species not only in our region, but also in the rest of Europe. This focus on the hidden biodiversity of terebellids can be translated to other parts of the world and also to other families, the estimated number of remaining new polychaetes species being greater than 20000 (Pamungkas et al. 2019; Capa \& Hutchings 2021; Magalhães et al. 2021). An interesting challenge will now be to develop online user-friendly tools, like the Delta (Coleman et al. 2010) or Xper (Ung et al. 2010) identification keys. A new volume of the Fauna Iberica collection with a focus on terebellids is also in preparation and coordinated by Julio Parapar. Finally, a "European Terebellids Tour" to sample and erect neotypes of old species should be planned (Fig. 9)!

\section{Acknowledgements}

We would like to thank the Resomar Benthic Team and all the people involved in the sampling campaigns, surveys and research programs for providing us with the specimens examined in this study. We are very grateful to Ruth Barnich and the second reviewer for their thorough and constructive reviews. The 
study was partially funded by the Biodiversity Platform (EPOC laboratory, Arcachon) and generously supported by the Australian Museum, Sydney. Nicolas Lavesque and Guillemine Daffe have received financial support from the French State in the frame of the "Investments for the future" Programme IdEx Bordeaux, reference ANR-10-IDEX-03-02. JMMN receives a productivity grant from Conselho Nacional de Desenvolvimento Científico e Tecnológico (CNPq), level 2, Brazil.

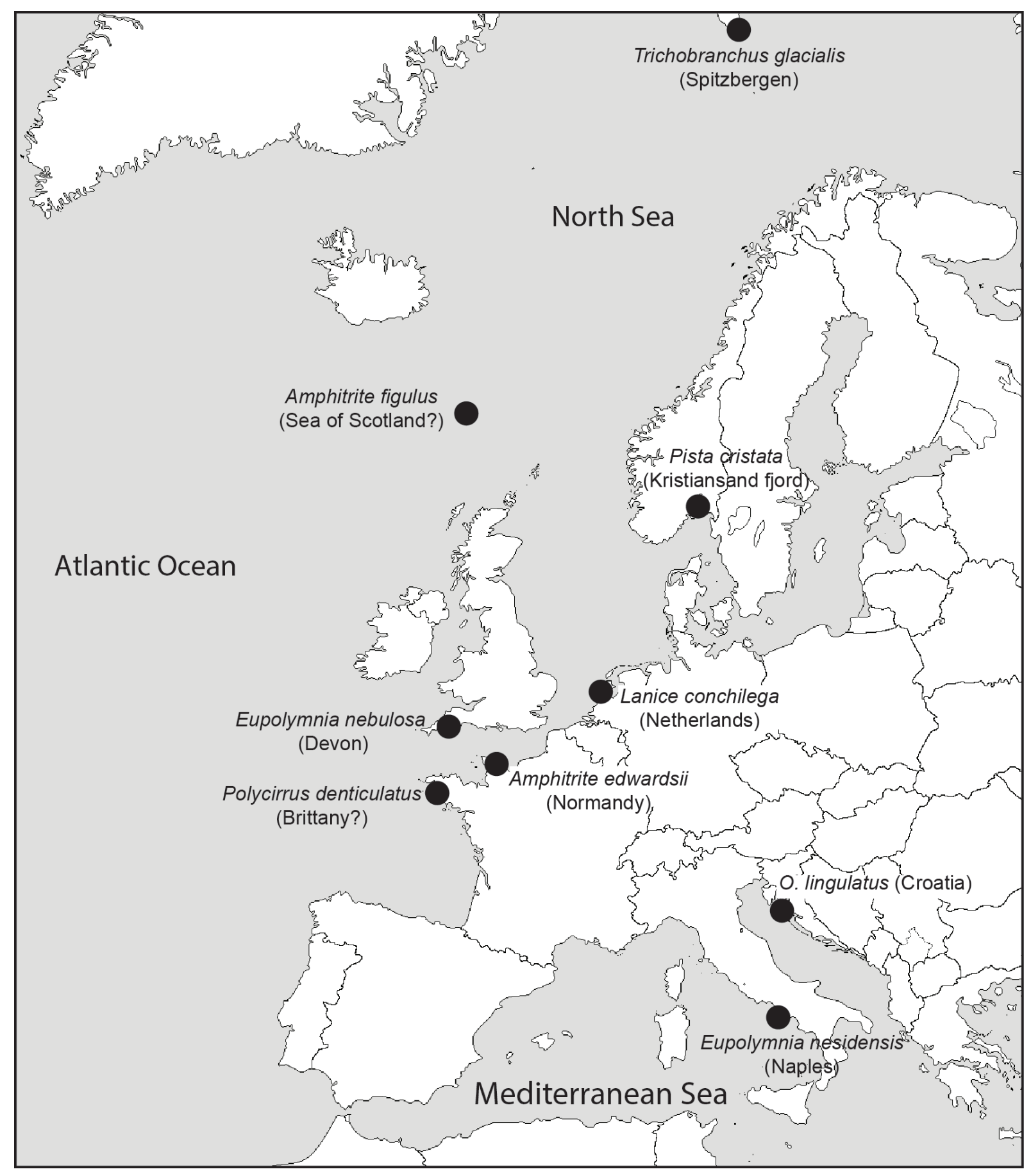

Fig. 9. Type localities of European species for which a neotype is required. 


\section{References}

Annenkova N.P. 1924. Neues über die Verbreitung einiger Arten der Polychaeten. Comptes Rendus de l'Académie des Sciences de Russie 1924: 125-128.

Arias A. \& Crocetta F. 2016. Umbraculum umbraculum (Gastropoda: Heterobranchia) spreading northwards: Additional evidence to the "tropicalization" of the Bay of Biscay. Cahiers de Biologie Marine 57: 285-206.

Arvanitidis C. \& Koukouras A. 1995. Amphitritides kuehlmanni sp. nov. (Polychaeta, Terebellidae, Amphitritinae) from the Aegean Sea, with comments on the genus Amphitritides Augener. Ophelia 40 (3): 219-227. https://doi.org/10.1080/00785326.1995.10430587

Augener H. 1922. Über littorale Polychaeten von Westindien. Sitzungsberichte der Gesellschaft naturforschender Freunde zu Berlin 1922 (3-5): 38-63.

Barbera C., Bordehore C., Borg J.A., Glémarec M., Grall J., Hall-Spencer J.M., De La Huz C., Lanfranco E., Lastra M., Moore P.G., Mora J., Pita M.E., Ramos-Esplá A.A., Rizzo M., SánchezMata A., Seva A., Schembri P.J. \& Valle C. 2003. Conservation and management of northeast Atlantic and Mediterranean maerl beds. Aquatic Conservation Marine and Freshwater Ecosystems 13: 65-76. https://doi.org/10.1002/aqc.569

Bhaud M. 1988. Influence of temperature and food supply on development of Eupolymnia nebulosa (Montagu, 1818) (Polychaete, Terebellidae). Journal of Experimental Marine Biology and Ecology 118: 103-113. https://doi.org/10.1016/0022-0981(88)90234-1

Bhaud M. \& Grémare A. 1988. Larval development of the the terebellid polychaete Eupolymnia nebulosa (Montagu) in the Mediterranean Sea. Zoologica Scripta 17: 347-356.

https://doi.org/10.1111/j.1463-6409.1988.tb00111.x

Bickford D., Lohman D.J., Sodhi N.S., Ng P.K.L., Meier R., Winker K., Ingram K.K. \& Das I. 2007. Cryptic species as a window on diversity and conservation. Trends in Ecology and Evolution 22: 148155. https://doi.org/10.1016/j.tree.2006.11.004

Blake J.A. \& Lavesque N. 2017. A new species of Chaetozone (Polychaeta, Cirratulidae) from the Bay of Biscay offshore France, together with a review of Chaetozone species from the North Atlantic and adjacent waters. Zootaxa 4312 (3): 565-579. https://doi.org/10.11646/zootaxa.4312.3.10.

Bonifácio P., Lavesque N., Bachelet G. \& Parapar J. 2015. Anobothrus amourouxi sp. nov., a new species of Ampharetidae (Polychaeta) from the Capbreton Canyon (Bay of Biscay, NE Atlantic Ocean). Journal of the Marine Biological Association of the United Kingdom 95 (5): 961-969. https://doi.org/10.1017/S0025315414002094

Capa M. \& Hutchings P. 2021. Annelid diversity: historical overview and future perspectives. Diversity 13: 129. https://doi.org/10.3390/d13030129.

Caullery M. 1915. Sur les Térébelliens de la sous-famille Polycirridae Malmgr. 1. Délimitation des genres. 11. Polycirrus arenivorus n.sp. Société Zoologique de France Bulletin 40: 239-248.

Cepeda D. \& Lattig P. 2016. A new species of Polycirridae (Annelida: Terebellida) and three new reports for Cantabrian and Mediterranean Seas. Cahiers de Biologie Marine 57: 371-387.

https://doi.org/10.21411/CBM.A.AE1327D3

Claparède E. 1864. Glanures zootomiques parmi les annélides de Port-Vendres (Pyrénées Orientales). Mémoires de la Société de Physique et d'Histoire naturelle de Genève 17 (2): 463-60.

https://doi.org/10.5962/bhl.title.1972 
Claparède E. 1870. Les annélides chétopodes du Golfe de Naples. Supplément. Mémoires de la Société de Physique et d'Histoire naturelle de Genève 20 (2): 365-542. https://doi.org/10.5962/bhl.title.2142

Coleman C.O., Lowry J.K. \& Macfarlane T. 2010. DELTA for beginners: an introduction into the taxonomy software package DELTA. ZooKeys 45: 1-75. https://doi.org/10.3897/zookeys.45.263

Dalyell J.G. 1853. The Powers of the Creator displayed in the Creation: or, Observations on Life amidst the various Forms of the humbler Tribes of animated Nature with practical Comments and Illustrations, Vol. 2. John van Voorst. London. https://doi.org/10.5962/bhl.title.10022

Day J.H. 1967. A Monograph on the Polychaeta of Southern Africa. Part 2. Sedentaria. Trustees of the British Museum (Natural History), London. https://doi.org/10.5962/bhl.title.8596

Eliason A. 1962. Die Polychaeten der Skagerak-Expedition 1933. Zoologiska bidrag från Uppsala 33: 207-293.

Encarnação J., Morais P., Baptista V., Cruz J. \& Teodósio M.A. 2019. New evidence of marine fauna tropicalization off the southwestern Iberian Peninsula (Southwest Europe). Diversity 11 (4): 48. https://doi.org/10.3390/d11040048

Fabricius O. 1780. Fauna Groenlandica, systematice sistens, Animalia Groenlandiae occidentalis hactenus indagata, quoad nomen specificum, triviale, vernaculumque synonyma auctorum plurium, descriptionem, locum, victum, generationem, mores, usum, capturamque singuli prout detegendi occasio fuit, maximaque parte secundum proprias observations. Impensis Ioannis Gottlob Rothe, Copenhagen et Leipzig [Hafniae et Lipsiae]. https://doi.org/10.5962/bhl.title.13489

Fauchald K. 1984. Polychaete distribution patterns, or: can animals with Palaeozoic cousins show largescale geographical patterns? In: Hutchings P. (ed.) Proceedings of the First International Polychaete Conference, July 1983, Sydney, Australia: 1-6. The Linnean Society of New South Wales, Sydney.

Fauvel P. 1913. Quatrième note préliminaire sur les polychètes provenant des campagnes de l'Hirondelle et de la Princesse-Alice, ou déposées dans la Musée océanographique de Monaco. Bulletin de l'Institut Océanographique 270: 1-80.

Fauvel P. 1918. Annélides polychètes nouvelles de l'Afrique Orientale. Bulletin du Muséum d'Histoire Naturelle 24: 503-509.

Fauvel P. 1923. Polychètes Errantes. Faune de France 5, Lechevalier, Paris.

Fauvel P. 1927. Polychètes Sédentaires. Addenda aux Errantes, Archiannélides, Myzostomaires. Faune de France 16, Lechevalier, Paris.

Fauvel P. 1932. Annelida Polychaeta of the Indian Museum, Calcutta. Memoirs of the Indian Museum 12: $1-262$.

Gaillande D. 1970. Une polychète Terebellidae nouvelle des côtes de Provence: Pista mediterranea n. sp. Téthys 2 (2): 443-448.

Garraffoni A.R.S. \& Lana P.C. 2004. Cladistic analysis of the subfamily Trichobranchinae (Polychaeta; Terebellidae). Journal of the Marine Biological Association of the United Kingdom 84: 973-982. https://doi.org/10.1017/S0025315404010264h

Gil J.C. 2011. The European Fauna of Annelida Polychaeta. PhD Thesis. University of Lisbon, Portugal.

Glasby C.J. \& Hutchings P. 2014. Revision of the taxonomy of Polycirrus Grube, 1850 (Annelida: Terebellida: Polycirridae). Zootaxa 3877 (1): 1-117. https://doi.org/10.11646/zootaxa.3877.1.1 
Glasby C.J., Hutchings P. \& Hall K. 2004. Assessment of monophyly and taxon affinities within the polychaete clade Terebelliformia (Terebellida). Journal of the Marine Biological Association of the United Kingdom 84: 961-971. https://doi.org/10.1017/S0025315404010252h

Godet L., Toupoint N., Olivier F., Fournier J. \& Retière C. 2008. Considering the functional value of common marine species as a conservation stake: the case of sandmason worm Lanice conchilega (Pallas 1766) (Annelida, Polychaeta) beds. AMBIO: A Journal of the Human Environment 37: 347-355. https://doi.org/10.1579/07-A-317.1

Grall J. \& Hall-Spencer J.M. 2003. Problems facing maerl conservation in Brittany. Aquatic Conservation Marine and Freshwater Ecosystems 13: 55-64. https://doi.org/10.1002/aqc.568

Grémare A. 1986. A comparative study of reproductive energetics in two populations of the terebellid polychaete Eupolymnia nebulosa Montagu with different reproductive modes. Journal of Experimental Marine Biology and Ecology 96: 287-302. https://doi.org/10.1016/0022-0981(86)90208-X

Grémare A. 1988. Feeding, tube-building and particle-size selection in the terebellid polychaete Eupolymnia nebulosa. Marine Biology 97: 243-252. https://doi.org/10.1007/BF00391309

Grémare A. \& Amouroux J.M. 1990. Feeding responses of the tentaculate deposit-feeder Eupolymnia nebulosa (Annelida: Polychaeta): influence of sexual maturity. Marine Biology 107: 315-319. https://doi.org/10.1007/BF01319831

Grémare A., Amouroux J.M. \& Amouroux J. 1989. Modelling of consumption and assimilation in the deposit-feeding polychaete Eupolymnia nebulosa. Marine Ecology Progress Series 54: 239-248. https://doi.org/10.3354/meps054239

Grube A.E. 1850. Die Familien der Anneliden. Archiv für Naturgeschichte 16 (1): 249-364. Available from https://www.biodiversitylibrary.org/page/6958350 [accessed 8 Nov. 2021].

Grube A.E. 1855. Beschreibungen neuer oder wenig bekannter Anneliden. Archiv für Naturgeschichte 21 (1): 81-136. Available from https://doi.org/10.5962/bhl.part.13989 [accessed 8 Nov. 2021].

Grube A.E. 1860. Beschreibung neuer oder wenig bekannter Anneliden. Beitrag: Zahlreiche Gattungen. Archiv für Naturgeschichte 26: 71-118. https://doi.org/10.5962/bhl.title.11291

Grube A.E. 1863. Beschreibung neuer oder wenig bekannter Anneliden. Sechster Beitrag. Archiv für Naturgeschichte 29: 37-69. Available from https://doi.org/10.5962/bhl.part.9306 [accessed 8 Nov. 2021].

Hartman O. 1959. Catalogue of the polychaetous annelids of the world. Part II. Occasional Papers of the Allan Hancock Foundation 23: 355-628.

Hartmann-Schröder G. 1996. Annelida, Borstenwürmer, Polychaeta. Die Tierwelt Deutschlands 58: $1-648$.

Hessle C. 1917. Zur Kenntnis der terebellomorphen Polychaeten. Zoologiska bidrag frän Uppsala 5: 39-258. Available from https://www.biodiversitylibrary.org/page/38891407 [accessed 8 Nov. 2021].

Holthe T. 1976. Paramphitrite tetrabranchia gen. et sp. nov. a new terebellid polychaete from western Norway. Sarsia 60: 59-62. https://doi.org/10.1080/00364827.1976.10411303

Holthe T. 1986. Polychaeta, Terebellomorpha. Marine Invertebrates of Scandinavia 7, Norwegian University Press, Oslo.

Hutchings P. 2020. Major issues facing taxonomy - a personal perspective. Megataxa 1: 46-48. https://doi.org/10.11646/megataxa.1.1.9 
Hutchings P. 2021. Potential loss of biodiversity and the critical importance of taxonomy - An Australian perspective. Advances in Marine Biology 88: 3-15. https://doi.org/10.1016/S0065-2881(21)00015-8

Hutchings P. \& Kupriyanova E. 2018. Cosmopolitan polychaetes - fact or fiction? Personal and historical perspectives. Invertebrate Systematics 32 (1): 1-9. https://doi.org/10.1071/IS17035

Hutchings P. \& Lavesque N. 2020. I know who you are, but do others know? Why correct scientific names are so important for the biological sciences. Zoosymposia 19: 151-163.

https://doi.org/10.11646/zoosymposia.19.1.16

Hutchings P., Nogueira J.M.N. \& Carrerette O. 2021a. Terebellidae Johnston, 1846. In: SchmidtRhaesa A.Hr., Beutel R.G., Glaubrecht M., Kristensen N.P., Prendini L., Purschke G., Richter S., Westheide, W. \& Leschen R.Z.E. (eds) Handbook of Zoology. A Natural History of the Phyla of the Animal Kingdom: 1-64. Walter de Gruyter \& Co, Berlin.

Hutchings P., Carrerette O., Nogueira J.M.N.N., Hourdez S. \& Lavesque N. 2021b. The Terebelliformiarecent developments, future directions. Diversity 13: 60. https://doi.org/10.3390/d13020060

Jirkov I. 2018. Three new species of Thelepus Leuckart, 1849 from Europe and a re-description of T. cincinnatus (Fabricius, 1780) (Annelida, Terebellidae). ZooKeys 759: 29-56.

https://doi.org/10.3897/zookeys.759.22981

Jirkov I. 2020. Review of the European Amphitrite (Polychaeta: Terebellidae) with description of two new species. Invertebrate Zoology 17 (4) 311-360. https://doi.org/10.3853/j.0067-1975.40.1988.150

Jirkov I., Ravara A. \& Cunha M.R. 2018; Amphitrite fauveli sp. n. (Polychaeta: Terebellidae) from the Bay of Biscay and the Gulf of Cadiz (NE Atlantic). Invertebrate Zoology 15 (1): 85-91. https://doi.org/10.15298/invertzool.15.1.06

Johnston G. 1846. An index to the British Annelides. Annals and Magazine of Natural History 1 (16): 433-462. https://doi.org/10.1080/037454809495980

Jourde J., Sampaio L., Barnich R., Bonifácio P., Labrune C., Quintino V. \& Sauriau P.G. 2015. Malmgrenia louiseae sp. nov., a new scale worm species (Polychaeta: Polynoidae) from southern Europe with a key to European Malmgrenia species Journal of the Marine Biological Association of the United Kingdom 95: 947-952. https://doi.org/10.1017/S0025315414001878

Kingston P.F. \& Mackie A.S.Y. 1980. Octobranchus floriceps sp. nov. (Polychaeta: Trichobranchidae) from the northern North Sea with a re-examination of O. antarcticus Monro. Sarsia 65: 249-254. https://doi.org/10.1080/00364827.1980.10431487

Labrune C., Lavesque N., Bonifácio P. \& Hutchings P. 2019. A new species of Pista Malmgren, 1866 (Annelida, Terebellidae) from the Western Mediterranean Sea. ZooKeys 838: 71-83.

https://doi.org/10.3897/zookeys.838.28634

Langerhans P. 1880. Die Wurmfauna von Madeira. III. Zeitschrift für wissenschaftliche Zoologie 34 (1): 87-143.

Langerhans P. 1884. Die Wurmfauna von Madeira. IV. Zeitschrift für wissenschaftliche Zoologie 40: $247-285$.

Lavesque N., Bonifácio P., Meißner K., Blanchet H., Gouillieux B., Dubois S. \& Bachelet G. 2015. New records of Spio symphyta and Spio martinensis ('Polychaeta': Canalipalpata: Spionidae) from Arcachon Bay (France), NE Atlantic. Marine Biodiversity 45: 77-86. https://doi.org/10.1007/s12526-014-0230-7

Lavesque N., Bonifácio P., Londoño-Mesa M.H., Le Garrec V. \& Grall J. 2017a. Loimia ramzega sp. nov., a new giant species of Terebellidae (Polychaeta) from French waters (Brittany, English 
Channel). Journal of the Marine Biological Association of the United Kingdom 97 (5): 935-942. https://doi.org/10.1017/S0025315417000571

Lavesque N., Daffe G., Bonifácio P. \& Hutchings P. 2017b. A new species of the Marphysa sanguinea complex from French waters (Bay of Biscay, NE Atlantic) (Annelida, Eunicidae). ZooKeys 716: 1-17. https://doi.org/10.3897/zookeys.716.14070

Lavesque N., Hutchings P., Daffe G., Nygren A. \& Londoño-Mesa M.H. 2019a. A revision of the French Trichobranchidae (Polychaeta), with descriptions of nine new species. Zootaxa 4664 (2): 151-190. https://doi.org/10.11646/zootaxa.4664.2.1

Lavesque N., Daffe G., Grall J., Zanol J., Gouillieux B., Hutchings P. 2019b. Guess who? On the importance of using appropriate name: case study of Marphysa sanguinea (Montagu, 1813). ZooKeys 859: 1-15. https://doi.org/10.3897/zookeys.859.34117

Lavesque N., Londoño-Mesa M.H., Daffe G. \& Hutchings P. 2020a. A revision of the French Telothelepodidae and Thelepodidae (Annelida, Terebelliformia), with descriptions of three species and first European record of a non-indigenous species. Zootaxa 4810 (2): 305-327.

https://doi.org/10.11646/zootaxa.4810.2.4

Lavesque N., Hutchings P., Daffe G. \& Londoño-Mesa M.H. 2020b. Revision of the French Polycirridae (Annelida, Terebelliformia), with descriptions of eight new species. Zootaxa 4869 (2): 151-186. https://doi.org/10.11646/zootaxa.4869.2.1

Lavesque N., Hutchings P., Abe H., Daffe G., Gunton L.M. \& Glasby C.J. 2020c. Confirmation of the exotic status of Marphysa victori Lavesque, Daffe, Bonifácio \& Hutchings, 2017 (Annelida) in French waters and synonymy of Marphysa bulla Liu, Hutchings \& Kupriyanova, 2018. Aquatic Invasions 15: 355-366. https://doi.org/10.3391/ai.2020.15.3.01

Lavesque N., Daffe G., Londoño-Mesa M.H. \& Hutchings P. 2021. Revision of the French Terebellidae sensu stricto (Annelida, Terebelliformia), with descriptions of nine species. Zootaxa 5038 (1): 1-63. https://doi.org/10.11646/zootaxa.5038.1.1

Le Garrec V., Grall J., Chevalier C., Guyonnet B., Jourde J., C., Lavesque N., Bonifácio P. \& Blake J.A. 2017. Chaetozone corona (Polychaeta, Cirratulidae) in the Bay of Biscay: a new alien species for the North-east Atlantic waters? Journal of the Marine Biological Association of the United Kingdom 97: 433-445. http://doi.org/10.1017/S0025315416000540

Leuckart R. 1849. Zur Kenntnis der Fauna von Island. Archiv für Naturgeschichte 15 (1): 149-208.

Levinsen G.M.R. 1893. Annulata, Hydroidae, Anthozoa, Porifera. Udbytte af Kanonbaaden "Hauche" togter i de Danske indenfor Skagen i Aarene 1893: 321-464.

Lezzi M. \& Giangrande A. 2019. New species of Streblosoma (Thelepodidae, Annelida) from the Mediterranean Sea: S. pseudocomatus sp. nov., S. nogueirai sp. nov. and S. hutchingsae sp. nov. Journal of Natural History 52 (43-44): 2857-2873. https://doi.org/10.1080/00222933.2018.1556357

Linnaeus C. 1767. Systema Naturae per regna tria naturae, secundum classes, ordines, genera, species, cum characteribus, differentiis, synonymis, locis. Editio duodecima reformata. Typis Ioannis Thomae von Trattner, Wien [Vindobonae]. https://doi.org/10.5962/bhl.title.156772

Lima F.P., Ribeiro P.A., Queiroz N., Hawkins S.J. \& Santos A.M. 2007. Do distributional shifts of northern and southern species of algae match the warming pattern? Global Change Biology 13: 25922604. https://doi.org/10.1111/j.1365-2486.2007.01451.x

Maire O., Duchêne J.C., Amouroux J.M. \& Grémare A. 2007. Activity patterns in the terebellid polychaete Eupolymnia nebulosa assessed using a new image analysis system. Marine Biology 151: 737-749. https://doi.org/10.1007/s00227-006-0519-6 
Magalhães W.F., Hutchings P., Oceguera-Figuero A., Martin P., Schmelz R.M, Wetzel M.J., Wiklund H., Macioloek N.J., Kawauchi G.Y. \& Williams J.D. 2021. Segmented worms (Phylum Annelida): a celebration of twenty years of progress through Zootaxa and call for action on the taxonomic work that remains. Zootaxa 4979 (1): 190-211. https://doi.org/10.11646/zootaxa.4979.1.18

Malm A.W. 1874. Annulata i hafvet utmed Sveriges westkust och omkring Göteborg. Göteborgs Königlich vetenskaps - och vitterhetssamhälles handlingar [Zoologiska observationer. VII.] 14: 67-105.

Malmgren A.J. 1866. Nordiska Hafs-Annulater. Öfversigt af Kongliga Vetenskaps-Akademiens Förhandlingar 22: 355-410. Available from https://www.biodiversitylibrary.org/part/244483 [accessed 8 Nov. 2021].

Marenzeller E. 1884. Südjapanische Anneliden. II. Ampharetea, Terebellacea, Sabellacea, Serpulacea. Denkschriften der Akademie der Wissenschaften, Mathematisch-Naturwissenschaftliche Classe 49 (2): 197-224.

Marion A.F. \& Bobretzky N.V. 1875. Étude des Annélides du Golfe de Marseille. Annales des Sciences Naturelles, Sixième Série 2: 1-106. Available from https://www.biodiversitylibrary.org/page/33155516 [accessed 8 Nov. 2021].

Martin D., Cha J.H. \& Bhaud M. 1996. Consequences of oocyte form modifications in Eupolymnia nebulosa (Annelida; Polychaeta). Invertebrate Reproduction \& Development 29: 27-36.

https://doi.org/10.1080/07924259.1996.9672492.

McIntosh W.C. 1869. On the structure of the British nemerteans, and some new British annelids. Transactions Royal Society of Edinburgh 25: 249-252. https://doi.org/10.1017/S0080456800035262

McIntosh W.C. 1885. Report on the Annelida Polychaeta collected by H.M.S. Challenger during the years 1873-1876. Report on the Scientific Results of the Voyage of H.M.S. Challenger during the years 187376. Zoology 12: 1-554. Available from https://www.biodiversitylibrary.org/page/50688432 [accessed 8 Nov. 2021].

McIntosh W.C. 1915. Notes from the Gatty Marine Laboratory, St Andrews. Annals and Magazine of Natural History Series 8 15: 1-58. https://doi.org/10.1080/00222931508693614

Mikac B. \& Hutchings P. 2017. One new species of Pista Malmgren, 1866 (Annelida: Terebellidae) and one new species of Pistella Hartmann-Schröder, 1996 (Annelida: Terebellidae) from the Adriatic Sea (Mediterranean). Journal of the Marine Biological Association of the United Kingdom 97 (5): 943-953. https://doi.org/10.1017/s0025315417000868

Montagu G. 1813. Descriptions of several new or rare animals, principally marine, found on the south coast of Devonshire. Transactions of the Linnean Society of London 11: 18-21.

https://doi.org/10.1111/j.1096-3642.1813.tb00035.x

Montagu G. 1819. Descriptions of five British species of the genus Terebella. Transactions of the Linnean Society of London 12 (2): 340-344. https://doi.org/10.1111/j.1095-8339.1817.tb00231.x

Müller O.F. 1771. Von Würmern des süssen und salzigen Wassers. Mumme \& Faber, Copenhagen. https://doi.org/10.5962/bhl.title.14428

Müller O.F. 1776. Zoologicae Danicae Prodromus, seu Animalium Daniae et Norvegiae indigenarum characteres, nomina et synonyma imprimis popularium. Hallageriis, Copenhagen [Havniae].

https://doi.org/10.5962/bhl.title.63795

Nogueira J.M.M. 2019. Redescriptions of Streblosoma bairdi (Malmgren, 1866) and Thelepus cincinnatus (Fabricius, 1780), based on types and material from type localities. Zootaxa 4544 (3): 419428. https://doi.org/10.11646/zootaxa.4544.3.7 
Nogueira J.M.M., Hutchings P. \& Fukuda M.V. 2010. Morphology of terebelliform polychaetes (Annelida: Polychaeta: Terebelliformia), with a focus on Terebellidae. Zootaxa 2460 (1): 1-185. https://doi.org/10.11646/zootaxa.2460.1.1

Nogueira J.M.M., Fitzhugh K. \& Hutchings P. 2013. The continuing challenge of phylogenetic relationships in Terebelliformia (Annelida: Polychaeta). Invertebrate Systematics 27: 186-238. https://doi.org/10.1071/IS12062.

Nogueira J.M.M., Carrerette O., Hutchings P. \& Fitzhugh K. 2018. Systematic review of the species of the family Telothelepodidae Nogueira, Fitzhugh \& Hutchings, 2013 (Annelida, Terebelliformia), with descriptions of three new species. Marine Biology Research 14: 217-257.

https://doi.org/10.1080/17451000.2017.1401729.

Nygren A. 2014. Cryptic polychaete diversity: a review. Zoologica Scripta 43: 172-183. https://doi.org/10.1111/zsc.12044

Nygren A., Parapar J., Pons J., Meißner K., Bakken T., Kongsrud J.A., Oug E., Gaev D., Sikorski A., Johansen R.A., Hutchings P., Lavesque N. \& Capa M. 2018. A megacryptic species complex hidden among one of the most common annelids in the North East Atlantic. PLoS One 13 (6): e0198356. https://doi.org/10.1371/journal.pone.0198356

Ørsted A.S. 1844. Zur Classification der Annulaten mit Beschreibung einiger neuer oder unzulänglich bekannter Gattungen und Arten. Archiv für Naturgeschichte 10(1): 99-112. Available from https://www.biodiversitylibrary.org/page/13704002 [accessed 8 Nov. 2021].

Pallas P.S. 1766. Miscellanea Zoologica quibus novae imprimis atque obscurae animalium species describunture et observationibus iconibusque illustrantur. Apud Petrum van Cleef, the Hague [Hague Comitum]. https://doi.org/10.5962/bhl.title.69851

Pamungkas J., Glasby C.J., Read G.B. Wilson S.P. \& Costello M.J. 2019. Progress and perspectives in the discovery of polychaete worms (Annelida) of the world. Helgoland Marine Research 73: 4.

https://doi.org/10.1186/s10152-019-0524-Z

Parapar J. \& Hutchings P. 2014. Redescription of Terebellides stroemii (Polychaeta, Trichobranchidae) and designation of a neotype. Journal of the Marine Biological Association of the United Kingdom 95: 323-337. https://doi.org/10.1017/S0025315414000903

Parapar J., Moreira J. \& Helgason G.V. 2011. Taxonomy and distribution of Terebellides (Polychaeta, Trichobranchidae) in Icelandic waters, with the description of a new species. Zootaxa 2983 (1): 1-20. https://doi.org/10.11646/zootaxa.2983.1.1

Parapar J., Mikac B. \& Fiege D. 2013. Diversity of the genus Terebellides (Polychaeta: Trichobranchidae) in the Adriatic Sea with the description of a new species. Zootaxa 3691 (3): 333-350. https://doi.org/10.11646/zootaxa.3691.3.3

Parapar J., Moreira J. \& O’Reilly M. 2016. A new species of Terebellides (Polychaeta: Trichobranchidae) from Scottish waters with an insight into branchial morphology. Marine Biodiversity 46 (3): 211-225. https://doi.org/10.1007/s12526-015-0353-5

Parapar J., Capa M., Nygren A. \& Moreira J. 2020a. To name but a few: descriptions of five new species of Terebellides (Annelida, Trichobranchidae) from the North East Atlantic. ZooKeys 992: 1-58.

https://doi: 10.3897/zookeys.992.55977

Parapar J., Martin D. \& Moreira J. 2020b. On the diversity of Terebellides (Annelida, Trichobranchidae) in West Africa, seven new species and the redescription of T. africana Augener, 1918 stat. prom. Zootaxa 4771 (1): 1-61. https://doi.org/10.11646/zootaxa.4771.1.1. 
Pearson T.H. 1969. Scionella lornensis sp. nov., a new terebellid (Polychaeta: Annelida) from the west coast of Scotland, with notes on the genus Scionella Moore, and a key to the genera of the Terebellidae recorded from European waters. Journal of Natural History 3(4): 509-516.

https://doi.org/10.1080/00222936900770441

Polloni P.T., Rowe G.T. \& Teal J.M. 1973. Biremis blandi (Polychaeta: Terebellidae), new genus, new species, caught by D.S.R.V. "Alvin" in the Tongue of the Ocean, New Providence, Bahamas. Marine Biology 20: 170-175. https://doi.org/10.1007/BF00351456

Quatrefages A. de. 1866. Note sur la Classification des Annélides. Annales des Sciences Naturelles 5: 253-296.

Rabaut M., Vincx M. \& Degraer S. 2009. Do Lanice conchilega (sandmason) aggregations classify as reefs? Quantifying habitat modifying effects. Helgoland Marine Research 63: 37-46.

https://doi.org/10.1007/s10152-008-0137-4

Read G. \& Fauchald K. (eds) 2021. World Polychaeta Database. Terebellidae Johnston, 1846. Available from http://www.marinespecies.org/aphia.php?p=taxdetails\&id=982 [accessed 6 Oct. 2021].

Risso A. 1826. Histoire naturelle des principales productions de l'Europe méridionale et particulièrement de celles des environs de Nice et des Alpes Maritimes. Volume 4. Levrault, Paris.

https://doi.org/10.5962/bhl.title.58984

Saint-Joseph A. 1894. Annélides Polychètes des côtes de Dinard. Troisième Partie. Annales des Sciences naturelles Zoologie et Paléontologie 17: 1-395.

Saint-Joseph A. 1899. Annélides polychètes de la rade de Brest et de Paimpol. Annales des Sciences naturelles, Zoologie et Paléontologie, Série 8 10: 161-19.

Saphronova M.A. 1988. On cosmopolitan distribution of Pista cristata (Polychaeta, Terebellidae). Zoologicheskii zhurnal 67 (6): 888-897.

Sars M. 1835. Beskrivelser og Iagttagelser over nogle maerkelige eller nye i Havet ved den Bergenske Kyst Levende Dyr af Polypernes, Acalephernes, Radiaternes, Annelidernes og Molluskernes classer, med en kort Oversigt over de hidtil af Forfatteren sammesteds fundne Arter og deres Forekommen. T. Hallager, Bergen. https://doi.org/10.5962/bhl.title.13017

Sars M. 1863. Geologiske og zoologiske lagttagelser, anstillede paa en Reise i en Deel af Trondhjems stift i Sommeren 1862. Nyt magazin for naturvidenskaberne 12: 253-340. Available from https://biodiversitylibrary.org/page/8058512 [accessed 8 Nov. 2021].

Sars M. 1865. Fortsatte Bidrag til Kundskaben om Norges Annelider. Forhandlinger $i$ VidenskabsSelskabet i Christiania 1864: 5-20. Available from https://biodiversitylibrary.org/page/44007149 [accessed 8 Nov. 2021].

Sars G.O. 1872. Diagnoser af nye Annelider fra Christianiaforden, efter Professor M. Sar's efterladte Manuskripter. Forhandlinger i Videnskabs-Selskabet i Christiania 1871: 406-417. Available from https://biodiversitylibrary.org/page/44067540 [accessed 8 Nov. 2021]

Savigny J.C. 1822. Système des annélides, principalement de celles des côtes de l'Égypte et de la Syrie, offrant les caractères tant distinctifs que naturels des Ordres, Familles et Genres, avec la Description des Espèces. Description de l'Égypte ou Recueil des Observations et des Recherches qui ont été faites en Égypte pendant l'Expédition de l'Armée française, publié par les Ordres de sa Majesté l'Empereur Napoléon le Grand, Histoire Naturelle, Paris 1 (3): 1-128. https://doi.org/10.5962/bhl.title.66284

Schäfer S., Monteiro J., Castro N., Rilov G. \& Canning-Clode J. 2019. Cronius ruber (Lamarck, 1818) arrives to Madeira Island: a new indication of the ongoing tropicalization of the northeastern Atlantic. Marine Biodiversity 49: 2699-2707. https://doi.org/10.1007/s12526-019-00999-z 
Southward E.C. 1956. On some Polychaeta of the Isle of Man. Annals and Magazine of Natural History Series 129 (100): 257-270. https://doi.org/10.1080/00222935608655812

Ssolowiew M. 1899. Polychaeten-Studien I. Die Terebelliden des Weissen Meeres. Annuaire du Musée Zoologique de l'Académie Impériale des Sciences de St. Pétersbourg 4 (2): 179-220. Available from https://biodiversitylibrary.org/page/39099726 [accessed 8 Nov. 2021].

Ung V., Dubus G., Zaragüeta-Bagils R. \& Vignes-Lebbe R. 2010. Xper2: introducing e-taxonomy. Bioinformatics 26: 703-704. https://doi.org/10.1093/bioinformatics/btp715

Van Hoey G., Guilini K., Rabaut M., Vincx M. \& Degraer S. 2008. Ecological implications of the presence of the tube-building polychaete Lanice conchilega on soft-bottom benthic ecosystems. Marine Biology 154: 1009-1019. https://doi.org/10.1007/s00227-008-0992-1

Verrill A.E. 1879. Preliminary Check-list of the marine Invertebrata of the Atlantic Coast, from Cape Cod to the Gulf of St. Lawrence. Tuttle, Morehouse \& Taylor, New Haven.

Verrill A.E. 1900. Additions to the Turbellaria, Nemertina, and Annelida of the Bermudas, with a revision of the New England genera and species. Transactions of the Connecticut Academy of Arts and Sciences 10: 595-671. Available from https://doi.org/10.5962/bhl.part.7035 [accessed 8 Nov. 2021].

Wesenberg-Lund E. 1950. Polychaeta. The Danish Ingolf-Expedition 4 (14): 1-92. Available from https://www.biodiversitylibrary.org/page/16847382 [accessed 8 Nov. 2021].

Williams S.J. 1984. The status of Terebellides stroemi (Polychaeta; Trichobranchidae) as a cosmopolitan species, based on a worldwide morphological survey, including description of new species. In: Hutchings P.A. (ed.) Proceedings of the First International Polychaete Conference, Sydney, Australia, 1984: 118-142. The Linnean Society of New South Wales, Sydney, Australia.

Wollebæk A. 1912. Nordeuropæiske Annulata Polychaeta 1. Ammocharidae, Amphictenidae, Ampharetidae, Terebellidae og Serpulidae. Skrifter utgit av Videnskapsselskapet i Kristiana 1911.1. Mathematisk-naturvidenskabelig klasse 1911 (18): 1-144. https://doi.org/10.5962/bhl.title.11634

Manuscript received: 13 August 2021

Manuscript accepted: 19 October 2021

Published on: 14 December 2021

Topic editor: Tony Robillard

Desk editor: Pepe Fernández

Printed versions of all papers are also deposited in the libraries of the institutes that are members of the EJT consortium: Muséum national d'histoire naturelle, Paris, France; Meise Botanic Garden, Belgium; Royal Museum for Central Africa, Tervuren, Belgium; Royal Belgian Institute of Natural Sciences, Brussels, Belgium; Natural History Museum of Denmark, Copenhagen, Denmark; Naturalis Biodiversity Center, Leiden, the Netherlands; Museo Nacional de Ciencias Naturales-CSIC, Madrid, Spain; Real Jardín Botánico de Madrid CSIC, Spain; Zoological Research Museum Alexander Koenig, Bonn, Germany; National Museum, Prague, Czech Republic. 